\title{
Organella bezbłonowe a separacja faz ciecz-ciecz - metody ich badań
}

\section{STRESZCZENIE}

$\mathrm{O}$ ganella bezbłonowe (ang. membraneless organelles, MLOs) stanowią sporą grupę kompartmentów wewnątrzkomórkowych formowanych na różnych etapach życia komórki. Są one niezbędnymi strukturami umożliwiającymi komórce pełnienie istotnych funkcji życiowych i właściwą odpowiedź na stres. MLOs obecne są zarówno w cytoplazmie jak i w innych organellach głównie w jądrze komórkowym. Powstają na drodze spontanicznej separacji faz ciecz-ciecz (ang. liquid-liquid phase separation, LLPS) w odpowiedzi na zmieniające się czynniki fizykochemiczne mikrootoczenia. Składają się zarówno z białek, które najczęściej posiadają regiony inherentnie nieuporządkowane (ang. intrinsically disordered regions, IDRs) jak i kwasów nukleinowych - głównie RNA. Niniejsza praca przedstawia informacje o biofizycznych podstawach formowania i funkcjonowania MLOs oraz zjawiska odpowiedzialnego za ich formowania, tj. LLPS. Zawiera także przegląd technik stosowanych w biochemii i biologii molekularnej, które za cel mają dostarczenie informacji o samoregulacji składu, struktury poszczególnych składników i ich lokalizacji oraz funkcjonalności danego MLO.

\section{WSTĘP}

Komórka, jako podstawowa jednostka strukturalna i funkcjonalna żywego organizmu przeprowadza równocześnie niezliczone reakcje chemiczne. Prawidłowe jej funkcjonowanie możliwe jest dzięki wyodrębnieniu specyficznych kompartmentów - organelli separujących procesy biochemiczne. Organella posiadają określony skład molekularny, co wynika m.in. ze ściśle regulowanej selekcji cząsteczek, które do danego organellum mogą wnikać oraz z niego wypływać. W utrzymaniu tożsamości molekularnej większości organelli komórkowych ważną rolę odgrywa błona lipidowa stanowiąca fizyczną barierę oraz filtr selektywności [1]. Jednak odkrycia ostatniej dekady pokazały, iż prawidłowe funkcjonowanie komórki, w dużej mierze zależy od kondensatów ${ }^{1}$ makromolekularnych, które są integralnymi strukturami, choć nie otacza ich błona komórkowa [2-6]. W większości przypadków te tzw. organella bezbłonowe (ang. membraneless organelles, $\mathrm{MLOs}^{2}$ ), granule czy ciałka komórkowe (ang. cellular bodies) tworzą się na pewnych etapach cyklu komórkowego oraz pod wpływem sygnałów dochodzących z otoczenia [7,8]. Nasuwa się pytanie, jaki jest charakter fizykochemiczny, mechanizm formowania i funkcjonowania organelli bezbłonowych. Dekadę temu w zespole Anthony'ego Hyman'a zauważono, że granule $\mathrm{P}$ tworzone $\mathrm{w}$ liniach germinalnych Caenorhabditis elegans zachowują się w cytoplazmie jak krople cieczy [9]. Krótko po tych obserwacjach, ci sami badacze dokonali podobnych spostrzeżeń badając jąderko [10] - najlepiej poznane i opisane MLO. Te odkrycia zapoczątkowały eksplozję badań nad właściwościami fizykochemicznymi innych MLOs. Dziś wiemy, że za ich formowanie odpowiadają zależności termodynamiczne znanego dobrze w chemii polimerów zjawiska separacji faz [2,11]. W zdecydowanej większości MLOs są cieczą, rzadziej żelem lub zolem. W związku z tym proces ich formowania nazwano separacją faz ciecz-ciecz (ang. liquid-liquid phase separation, LLPS) [11], przez niektórych nazywany także białkową separacją faz (ang. protein phase separation, PPS) [2] lub przejściem fazowym (ang. phase transition) [12]. W istocie termin separacja faz w kontekście MLOs nie jest formalnie poprawne. Separacja faz oznacza przejście danej substancji z jednego z trzech stanów skupienia (stały, ciekły, gazowy) w inny. W procesie, o którym mowa dochodzi raczej do wydzielenia frakcji. Frak${ }^{1}$ Kondensat oznacza skroplinę albo produkt powstały w wyniku kondensacji lub zagęszczania substancji (słownik PWN dostępny na: https://sjp.pwn.pl). W artykule, za literaturą anglojęzyczną, termin zastosowano do określenia zagęszczonej formy makromolekularnej powstałej na drodze LLPS niebędącej kompletnym pod względem składu i funkcjonalności organellum bezbłonowym. Zatem, w niniejszym artykule, termin kondensat określa ciekły kompleks makromolekularny, który można otrzymać in vitro lub kompleks wewnątrzkomórkowy, z którego tworzy się funkcjonalne MLOs

${ }^{2} \mathrm{~W}$ niniejszym artykule stosowany będzie skrót literowy MLO, który odnosić się będzie do pojedynczego organellum bezbłonowego oraz skrót MLOs, oznaczający, zgodnie z literaturą anglojęzyczną, większą ich grupę. Ta sama zasada będzie obowiązywać także dla innych skrótów.

\section{dr Aneta Tarczewska*®} mgr inż. Krzysztof Wycisk*, inż. Nikola Sozańska, prof. dr hab. inż. Andrzej Ożyhar

Katedra Biochemii, Biologii molekularnej i Biotechnologii, Wydział Chemiczny, Politechnika Wrocławska

*Autorzy mają taki sam wkład $\mathrm{w}$ napisanie artykułu

https://doi.org/10.18388/pb.2020_330

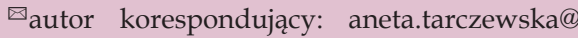
pwr.edu.pl

Słowa kluczowe: organella bezbłonowe, MLOs, separacja faz ciecz-ciecz, LLPS, przejście fazowe, IDR

Wykaz skrótów: DIC (ang. differential interference contrast) - różniczkowy kontrast interferencyjny; FRAP (ang. fluorescence recovery after photobleaching) - odzysk fluorescencji po fotoblaknięciu; IDRs (ang. intrinsically disordered regions) - regiony inherentnie nieuporządkowane; LCSs (ang. low complexity sequences) - sekwencje o niskim stopniu złożoności struktury; LLPS (ang. liquid-liquid phase separation) - separacja faz ciecz-ciecz; MLOs (ang. membraneless organelles) - organella bezbłonowe; NPM1 (ang. Nucleophosmin 1) - białko jąderkowe nukleofosmina 1; PML (ang. promyelocytic leukemia protein) - białko ostrej białaczki promielocytowej, główny składnik ciałek PML

Podziękowania: Praca została sfinansowana z dotacji Ministerstwa Nauki i Szkolnictwa Wyższego na działalność statutową Wydziału Chemicznego Politechniki Wrocławskiej. 


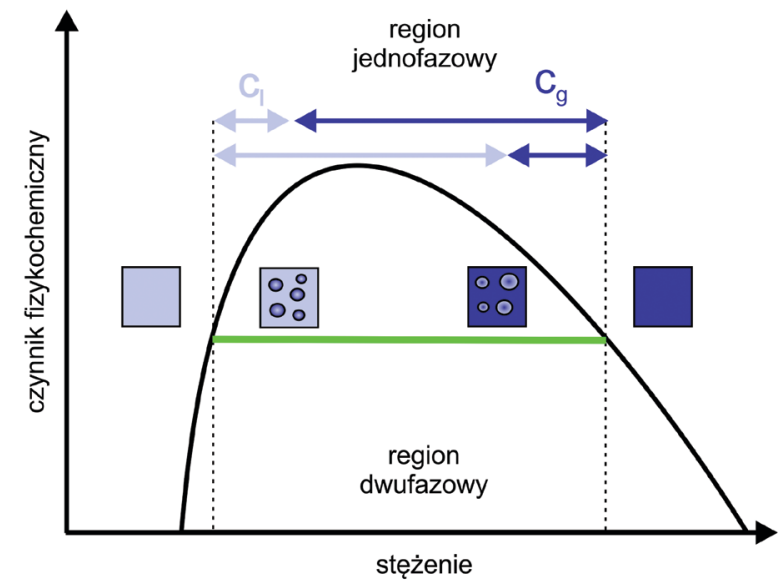

B

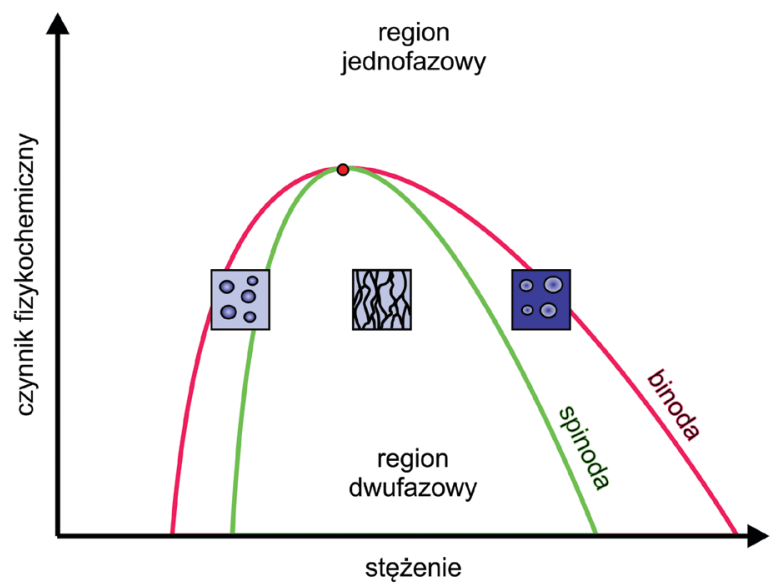

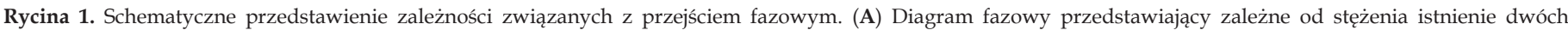

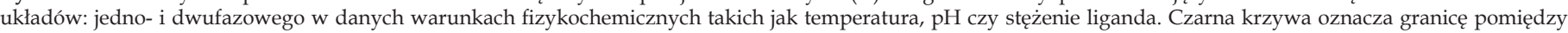

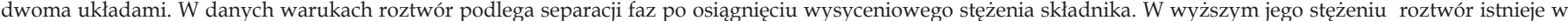

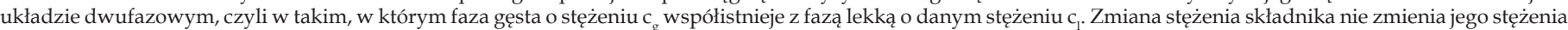

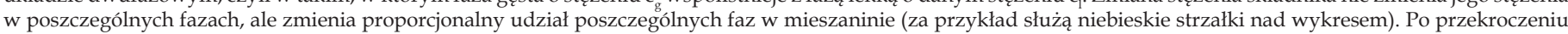

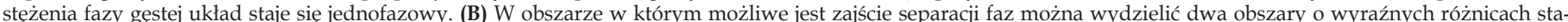

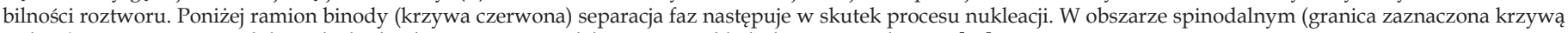
zieloną) roztwór jest niestabilny i dochodzi do spontanicznej dekompozycji składników. Na podstawie [18].

cja gęsta (ang. dense) wyodrębnia się z frakcji lekkiej (ang. li$g h t), \mathrm{tj} . \mathrm{z}$ homogennego roztworu makromolekuł. Następuje to po osiągnięciu krytycznego stężenia składnika w danych warunkach fizykochemicznych. Niemniej jednak określenie separacja faz zakorzeniło się głęboko w literaturze naukowej, a ponadto badania wskazują, że prawa i reguły dotyczące separacji faz, jak choćby prawidłowości opisane przez Flory'ego i Huggins'a [13,14], sprawdzają się w fizykochemicznym opisie zjawiska (Ryc. 1) [2,15-17]. Z tego względu w niniejszej pracy do opisania mechanizmu formowania i regulacji MLOs zastosowano termin separacji faz ciecz-ciecz (LLPS).

\section{FORMOWANIE ORGANELLI BEZBŁONOWYCH}

MLOs można uznać za krople cieczy stabilnie współistniejące w innej cieczy. Warto w tym miejscu zastanowić się, w jaki sposób dochodzi do ich formowania, skoro składają się one ze składników, które przed separacją tworzyły stabilną mieszaninę. Wiadomo, że w układach wieloskładnikowych często dochodzi do samoistnego mieszania się składników. Wynika to z dążenia układu do podniesienia poziomu entropii, czyli wzrostu stopnia nieuporządkowania. Istnieją jednak mieszaniny, głównie gazów lub cieczy, w których dochodzić może do spontanicznego rozdzielenia faz. Układy biologiczne są $\mathrm{z}$ reguły układami ciekłymi. W wyniku separacji faz z ciekłej cytoplazmy może wskutek precypitacji wydzielić się faza stała, jak to się dzieje w przypadku formowana elementów cytoszkieletu [19]. Możliwe jest także wydzielenie fazy ciekłej, tj. fazy amorficznej, bezpostaciowej, której składniki mają pełną swobodę przemieszczania się $\mathrm{w}$ danej objętości. Analizy in vitro dowodzą, że LLPS nie wymaga energii pochodzącej z hydrolizy ATP, ani nie posiada bariery energetycznej obniżanej przez aktywność enzymatyczną. Wykazano natomiast, że LLPS zachodzi spontanicznie podlegając prawom termodynamiki $[2,11,20,21]$. Według drugiego prawa termodynamiki pro- ces zachodzi spontanicznie, jeśli zmiana energii swobodnej Gibbsa $(\Delta G)$ danego procesu ma wartość ujemną. Wartość $\Delta \mathrm{G}$ jest funkcją czynników entalpowych i entropowych $(\Delta \mathrm{G}=\Delta \mathrm{H}-\mathrm{T} \Delta \mathrm{S})$. Dla układu, którego składniki są wymieszane, entropia mieszania przyjmuje wartość dodatnią. Jeśli w takim układzie dojdzie do separacji faz, układ staje się bardziej uporządkowany, stąd $\Delta S<0$. Wtedy separacja faz będzie zachodzić spontanicznie tylko, jeśli $\Delta \mathrm{H}<0$ i $\Delta \mathrm{H}<\mathrm{T} \Delta \mathrm{S}$ [14]. Za białkową separację faz odpowiadają bardzo słabe, wielorakie i zazwyczaj multiwalentne oddziaływania [22]. W układzie, w którym następuje spontaniczne mieszanie składników, molekuły przemieszczają się poprzez dyfuzję chemiczną zgodnie z pierwszym prawem Ficka:

$$
J=-D_{\bar{\delta} x^{\prime}}^{\delta c}
$$

gdzie: J - gęstość strumienia składnika, czyli ilość substancji przepływająca przez jednostkowy przekrój w jednostce czasu; D - współczynnik dyfuzji; c - stężenie, $x$ - odległość od źródła dyfundującej substancji. Dyfuzja następuje, jeśli istnieje gradient potencjału chemicznego. W systemie, w którym doszło do separacji faz, na granicy fazy gęstej i lekkiej, pomimo występowania sporych różnic w stężeniu składników, makroskopowy strumień dyfuzji nie występuje, ponieważ składniki dyfundują z jednakową prędkością w obydwu kierunkach. Dzieje się tak, gdyż nie ma różnicy potencjału chemicznego i obie fazy są stabilne termodynamicznie. Zatem zmiana czynników fizykochemicznych, takich jak np. temperatura, siła jonowa, stężenie makromolekuł czy nawet modyfikacje potranslacyjne, zmieniające np. ładunek danej reszty aminokwasowej, mogą wywołać spontaniczną LLPS w układach biologicznych [11]. Co ważne, w wyniku odziaływania molekuł, ciekły kondensat może ulegać przemianom w procesie dojrzewania (ang. aging), który prowadzi do utworzenia innej formy amorficznej charakteryzującej się mniejszą dynamiką relaksacyjną wynikającą z większego stopnia sieciowania makromolekuł lub nawet formy 

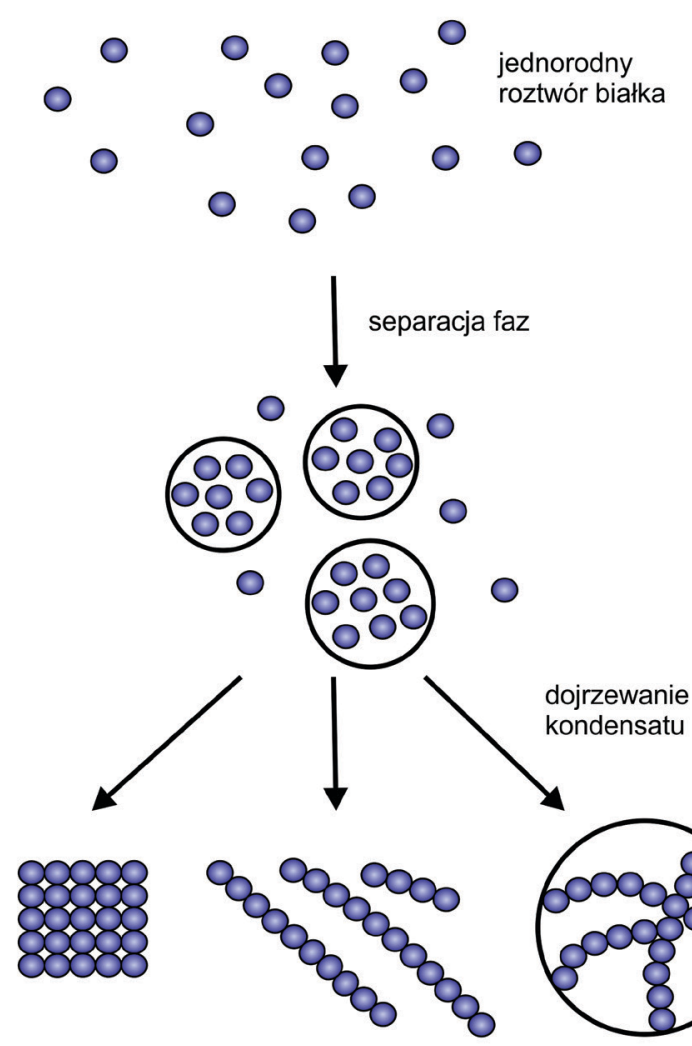

kryształ

włókna

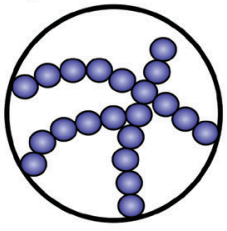

żel

Rycina 2. Dojrzewanie kondensatów molekularnych. W odpowiednich warunkach fizykochemicznych roztwór białka może ulec spontanicznej LLPS. Ciekły kondensat może z czasem ulec przemianom, w wyniku których powstaną inne formy amorficzne, tj. włókna czy żele białkowe, posiadające znacznie zmniejszoną swobodę kinetyczną. W wyniku przemian dochodzić także może do formowania stałej formy krystalicznej.

stałej (Ryc. 2) [2]. Przemiany i dojrzewanie kondensatów komórkowych stanowią obszar intensywnych badań, gdyż istnieje ścisły związek między zaburzeniami tego procesu, a rozwojem wielu patologicznych procesów komórkowych np. tworzeniem włókien amyloidowych $[4,6,23,24]$.

\section{REGULACJA SKŁADU ORGANELLI BEZBŁONOWYCH}

MLOs są wielomolekularnymi kompleksami składającymi się z białek i kwasów nukleinowych. Jednak, tylko niektóre z nich konieczne są do utrzymania integralności organellum [22]. Ciekawym sposobem opisu roli poszczególnych składników w utrzymaniu integralności strukturalnej i funkcjonalności kondensatu jest model zaproponowany przez Banani'ego i wsp. [25]. Model zakłada, że molekuły obecne w kondensacie można podzielić na dwie klasy. Pierwsze to molekuły stanowiące rusztowanie (ang. scaffolds) kondensatu. W ich strukturze wyróżnić dalej można sekwencje bezpośrednio zaangażowane $\mathrm{w}$ tworzenie oddziaływań zapewniających integralność kondensatu, tzw. metki (ang. stickers) oraz sekwencje oddzielające (ang. spacers). Drugą klasę składowych kondensatu stanowią tzw. klienci (ang. clients). Klienci stanowią większość składników kondensatów biomolekularnych a ich skład pozostaje zmienny. Ich obecność w kondensacie zapewniają motywy, które specyficznie wiążą się z metkami składników stanowiących rusztowanie [25]. Przykładowo, w ciałkach P funkcję rusztowania pełnią RNA oraz białka wiążące RNA. RNA jednocześnie rekrutuje do tego organellum inne białka wiążące kwasy nukleinowe, które jednak nie są niezbędnymi elementami zapewniającymi integralność organellum [26]. W obrębie kondensatu klienci dyfundują znacznie szybciej niż elementy stanowiące rusztowanie, co oznacza, iż oddziaływanie rusztowanie-klient jest znacznie słabsze niż oddziaływanie elementów stanowiących rusztowanie. Skład kondensatów kontrolowany jest m.in przez zagęszczenie elementów stanowiących rusztowanie, gdyż jest ono wprost skorelowane z licznością wolnych płaszczyzn do oddziaływania z klientami [25]. Model zaprezentowany przez Banani'ego i wsp. jest sporym uogólnieniem i w warunkach fizjologicznych w MLOs dochodzi najprawdopodobniej do bardziej złożonych odziaływań pomiędzy składnikami. Dodatkowo, składniki ulegają ciągłym modyfikacjom w wyniku reakcji biochemicznych. Dynamicznej zmianie ulega także otoczenie organelli np. na skutek zmiany profilu ekspresji genów wywołanej obecnością czynnika stresowego. Jednak powyższy model pozwala na opisanie i zrozumienie sposobu naturalnej regulacji składu danego kondensatu.

\section{ODDZIAŁYWANIA SPRZYJAJĄCE SEPARACJI FAZ}

Kwasy nukleinowe, głównie RNA, i niektóre białka stanowią rusztowanie MLOs [25]. Co decyduje o tym, że jedne białka promują LLPS, a inne nie? Czy istnieje cecha wspólna takich białek, a także określony wzór oddziaływań? Badania dowodzą, że $\mathrm{w}$ procesie LLPS pierwszorzędną rolę odgrywają białka posiadające regiony inherentnie nieuporządkowane (ang. intrinsically disordered regions, IDRs) [27]. Przykładowo, analizy bioinformatyczne wielu białek tworzących granule P wskazują na znaczny stopień nieuporządkowania łańcuchów polipeptydowych. Do białek tych zalicza się np. białka MEG (ang. Maternally expressed genes), których rola związana jest z biogenezą granul P [28], czy białko LAF-1 (ang. Lethal and feminizing 1) [29]. W przypadku IDRs, ważną rolę $\mathrm{w}$ procesie LLPS odgrywają sekwencje o małej złożoności składu aminokwasowego (ang. low complexity sequences, LCSs) $[27,30]$. Są one na przykład obecne w białkach hnRNPA1, hnRNPA2 (ang. Heterogeneous nuclear ribonucleoprotein A1, A2) i FUS (ang. Fused in sarcoma) biorących udział w tworzeniu tzw. granul stresowych [35]. Charakteryzuje je znaczna zawartość reszt polarnych (Gln, Asn, Ser), zasadowych (Lys i Arg), kwaśnych (Asp, Glu), a także zawartość reszt aromatycznych (Phe i Tyr). Co ważne, $\mathrm{w}$ obrębie LCSs reszty aminokwasowe często tworzą krótkie dwu-, trzy-aminokwasowe motywy, np. Tyr-Gly/Ser, Phe-Gly, Arg-Gly, Gly-Tyr, Lys-Ser-Glu-Ala, Ser-Tyr, lub zawierają po prostu sekwencje wzbogacone w niektóre reszty [15]. Szczegółowe badania kilku białek zaangażowanych w LLPS pozwoliły na zdefiniowanie typów odziaływań między- i wewnątrzcząsteczkowych, które stanowią podstawę formowania kondensatu molekularnego [31-34]. Wydaje się, że nie istnieje uniwersalny kod oddziaływania, który decydowałby o zdolności danego białka do tworzenia biologicznych kondensatów [22]. Zamiast tego $\mathrm{w}$ poszczególnych przypadkach obserwuje się różne typy oddziaływania, każdy w odmienny sposób wrażliwy na zmiany fizykochemiczne otoczenia (Ryc. 3A) [15]. Jednakowoż, cechą charakterystyczną tych oddziaływań jest ich multiwalentność. I tak, ważne w 
A

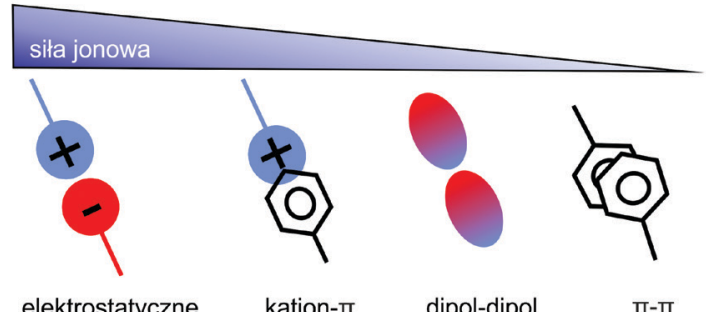

B

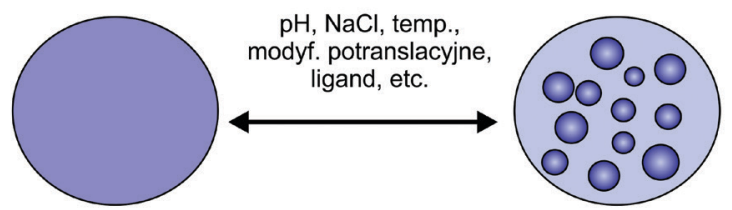

Rycina 3. Odziaływania cząsteczkowe prowadzące do LLPS. (A) Za formowanie kondensatów biomolekularnych odpowiedzialne są słabe oddziaływania pomiędzy różnymi grupami chemicznymi makrocząsteczek. Schemat przedstawia cztery rodzaje takich oddziaływań, które w największym stopniu przyczyniają się do tworzenia kondensatu. Odziaływania te wykazują inną wrażliwość na stężenie soli w roztworze. (B) LLPS, jako proces odwracalny, zależeć może od różnych czynników fizykochemicznych. Na podstawie [15].

tworzeniu multiwalentnych odziaływań są długodystansowe oddziaływania kulombowskie pomiędzy przeciwnie naładowanymi resztami. Tworzy je m.in. LAF-1 [29], czy obecna w granulach zarodkowych helikaza RNA DDX4 (ang. DEAD-Box Helicase 4) [35]. Istotne okazują się także krótkodystansowe oddziaływania pomiędzy dodatnio naładowanymi resztami Arg i polarnymi pierścieniami reszt Tyr, czyli oddziaływania typu kation-п. Przykład stanowi tutaj także DDX4 [9]. Spory udział w promowaniu LLPS maja także oddziaływania planarne typu п-п. Wśród nich największe znaczenie mają te formowane przez reszty Tyr, co sugeruje, że obecność grupy hydroksylowej wzmacnia odziaływania п-п [32]. Co ciekawe, oddziaływania dzięki którym formowane są MLOs, wydają się być w pewien sposób zhierarchizowane. Tworzenie kondensatów przez DDX4 prawdopodobnie rozpoczyna się od odziaływań elektrostatycznych pomiędzy przeciwnie naładowanymi resztami, później natomiast tworzone są oddziaływania typy kation-ח [15]. Co ciekawe, niektóre białka wiążące RNA obecne w MLOs zawierają w swojej budowie domeny podobne do prionów (PrLDs, ang. prion-like domains). Szczegółowe analizy PrLDs białka FUS i hnRNPA1 wykazały, że oddziaływania pomiędzy łańcuchami typu $\beta$, tworzone $\mathrm{z}$ udziałem tych białek, mogą prowadzić do LLPS [36]. Odziaływania te różnią się jednak od odziaływań $\beta$, które prowadzą do patologicznych procesów związanych z tworzeniem złogów amyloidowych [37]. Zatem, związek pomiedzy LLPS a biogenezą włókien amyloidowych wymaga dalszych, bardziej wnikliwych badań. Pewnym jest, że proces formowania ciekłego kondensatu a także jego rozpuszczenia, czyli powrót do jednorodnej mieszaniny (Ryc. 3B), zależny jest od wielu czynników. Ich poznanie przyczynić się może do zrozumienia molekularnych podstaw rozwoju wielu zaburzeń funkcjonowania komórki.

\section{FIZJOLOGIA KOMÓRKI A MLOs}

MLOs stanowią sporą grupę struktur komórkowych, bez których funkcje życiowe komórki oraz jej odpowiedź na czynniki zewnętrzne byłyby niemożliwe. Obecnie znanych jest kilkanaście typów MLOs formowanych w komórkach eukariotycznych [8]. Istnieją one zarówno $\mathrm{w}$ cytoplazmie jak i wewnątrz obłonionych organelli, tj. $w$ jądrze czy mitochondriach. Co ciekawe, niektóre struktury związane $\mathrm{z}$ błonami lipidowymi, jak choćby pory jądrowe, także wykazują właściwości kondensatów biomolekularnych [38]. Jednymi z najlepiej poznanych MLOs są jąderka [10]. Fakt, że jąderka są ciekłymi kondensatami pozwala zrozumieć ich dynamikę, możliwość szybkiego rozpadu i samoorganizacji w różnych fazach cyklu komórkowego, zmienny kształt i zmieniające się położenie $\mathrm{w}$ obrębie jądra komórkowego oraz możliwość wymiany składników z otoczeniem [39, 40]. Do nadrzędnych funkcji jąderka należy transkrypcja rDNA katalizowana przez polimerazę I [41], składanie podjednostek rybosomalnych $[42,43]$ oraz ochrona białek jądrowych przed nieodwracalną agregacją $\mathrm{w}$ warunkach stresu komórkowego [44]. W jąderku wyróżnić można kilka odrębnych obszarów różniących się składem molekularnym oraz pełnionymi funkcjami. I tak, w jąderku wyróżnia się składnik ziarnisty (ang. granular component, GC), gęsty składnik fibrylarny (ang. dense fibrillar component, DFC) oraz centrum fibrylarne (ang. fibrillar center, FC) [45]. Najbardziej zewnętrznym obszarem jąderka jest GC, który tworzą przede wszystkim ujemnie naładowane białka takie jak nukleolina i NPM1 (ang. Nucleophosmin 1) [46]. NPM1 jest oligomerycznym białkiem [47], które odgrywa nadrzędną rolę w promowaniu jąderkowej LLPS [43,48]. Dzięki multiwalentnym oddziaływaniom ujemnie naładowane i częściowo nieuporządkowane cząsteczki NPM1 oddziałują ze sobą tworząc GC. Następnie, NPM1 tworzy heterotropowe multiwalentne oddziaływania z rRNA i rybosomalnymi białkami posiadającymi dodatnio naładowane reszty, głównie reszty Arg [48]. Stanowi to podstawy procesu składania podjednostek rybosomalnych [43]. Innym ciekawym przykładem MLOs powstałych w wyniku LLPS są małe ciałka jądrowe odkryte na początku XX w. i nazwane od nazwiska odkrywcy ciałkami Cajala [49]. Ich markerowym białkiem jest koilina [50]. Co ciekawe jest ona jednocześnie białkiem jąderkowym [51]. To właśnie koilina powoduje, że ciałka Cajala zlokalizowane są nie tylko w nukleoplazmie, ale także niejednokrotnie formują się wewnątrz jąderek [52]. Ciekawą własnością ciałek Cajala jest ich szybkie przemieszczanie się $\mathrm{w}$ obszarze jądra komórkowego [53]. Zanim wiedza odnośnie LLPS wpisała się na dobre w kanon biologii molekularnej Platani i wsp. wykazali, że ciałka Cajala mogą ulegać fuzji i rozdziałowi podobnie jak krople cieczy [53]. Podobnie jak inne MLOs ciałka Cajala zawierają kompleksy białek i RNA, a ich funkcja związana jest głównie z powstawaniem, dojrzewaniem i przechowywaniem snRNP i snoRNP [54-57], co wiąże je pośrednio ze splicingiem. Ze splicingiem związane są także inne jądrowe MLOs, tzw. cętki jądrowe (ang. nuclear spec$k l e s)$. Zawierają one różne elementy maszynerii służącej do obróbki pre-mRNA. Do ich formowania dochodzi po podziale komórkowym oraz $w$ trakcie interfazy $[58,59]$. Sporo białek budujących cętki jądrowe posiada w swojej budowie LCS, w skład których wchodzą np. motywy bogate w Ser/ Arg [60]. Podobnie jak w przypadku ciałek Cajala, fakt iż 
cętki jądrowe są ciekłymi kondensatami powstałymi w wyniku LLPS tłumaczy ich sporą dynamikę oraz możliwość swobodnego przepływu składników miedzy cętkami a otaczającą nukleoplazmą [61], przy jednoczesnym zachowaniu ich spójności i integralności. Są to na tyle spójne struktury, że możliwe jest ich wyizolowanie z komórki metodami biochemicznymi [62]. Powstałe w wyniku LLPS MLOs odgrywają także ważną rolę w regulacji ekspresji genów poprzez epigenetyczne modyfikacje chromatyny. Główną rolę odgrywają tu duże kompleksy białek Polycomb [63]. W komórkach eukariotycznych heterochromatyna fakultatywna podlega modyfikacjom chemicznym [64]. Najważniejszą z nich jest trimetylacja Lys 27 w histonie H3 katalizowana przez białka kompleksu represorowego Polycomb 2 (ang. Polycomb repressive complex, PRC2) [65]. Zmodyfikowane miejsce histonu $\mathrm{H} 3$ jest następnie wiązane przez białka kompleksu represorowego Polycomb 1 (PRC1). Te z kolei wprowadzają kolejne modyfikacje białek nukleosomalnych regulując aktywność białek PRC2 [66,67]. Co ważne, zauważono, że białka Polycomb tworzą w nukleoplazmie punktowe skupiska $[68,69]$. Ostatnio Tatavosian i wsp. [70] wykazali, że białko Cbx2 (ang. Chromobox 2) będące częścią kompleksu PCR2, może promować LLPS. Sekwencjami promującymi LLPS w Cbx2 są zachowane ewolucyjnie regiony - głównie zasadowy region ATH2 (ang. AT-hook 2) i region bogaty w reszty Ser. Oba fragmenty znajdują się w IDR. Wartym podkreślenia jest fakt, że kondensaty Polycomb zawierają DNA [70]. LLPS jest procesem związanym z regulacją ekspresji genów, także na poziomie samej transkrypcji. Ostatnio Hnisz i wsp. [71] poddali analizie bioinformatycznej właściwości biofizyczne i biochemiczne kompleksów białkowych formowanych na super-wzmacniaczach (ang. super-enhancers). Super-wzmacniacze są sekwencjami DNA ważnymi dla inicjacji transkrypcji genów odpowiedzialnych za różnicowanie embrionalnych komórek macierzystych [72]. Zauważono, że kompleksy białkowe tworzone na super-wzmacniaczach posiadają specyficzne właściwości [73-75], odróżniające je od kompleksów tworzonych na zwyktych wzmacniaczach. Analiza bioinformatyczna przeprowadzona przez Hnisz i wsp. wskazała, że sposób formowania, regulacja składu, kooperatywność i dynamika inicjacji transkrypcji regulowana przez kompleksy formowane na super-wzmacniaczach wynikać mogą z faktu, iż kompleksy te są ciekłymi kondensatami powstającymi na drodze LLPS [71]. Analizy in vitro, którym poddano IDRs czynników transkrypcyjnych odpowiedzialnych za utrzymanie pluripotentności m.in. BRD4 (ang. Bromodomain-containing protein 4) i OCT-4 (ang. Octamer-binding transcription factor 4) w obecności podjednostki Med1 mediatora [76], stanowiącego główny składnik kompleksu, potwierdziły iż kompleksy białkowe formowane na super-wzmacniaczach powstają na drodze LLPS. Obecnie wiadomo, że regulacja transkrypcji, także w komórkach zróżnicowanych, odbywa się dzięki kondensatom makromolekularnym formowanym na drodze LLPS [77-80].

Z przytoczonych powyżej przykładów wynika, że regulacja ekspresji genów oraz następstwo zdarzeń na poziomie molekularnym zależne jest od prawidłowego formowania MLOs na drodze spontanicznej LLPS. Jednakże jądrowe MLOs związane są nie tylko z regulacją ekspresji genów. Przykładem mogą być klastrosomy będące dynamiczny- mi strukturami o nieregularnym kształcie. Formowane są one przejściowo w warunkach wymagających wzmożonej proteolizy w jądrze komórkowym. Powstają m.in. w czasie interfazy a ich główną funkcją jest specyficzna degradacja czynników transkrypcyjnych, np. onkoprotein, których aktywność musi być ściśle kontrolowana [81-83]. Po utworzeniu rekrutują kolejne białka ukierunkowane na degradację, jak na przykład białko PML (ang. Promyelocytic leukemia protein) [84]. PML wchodzi także w skład innych jądrowych MLOs, tj. ciałek PMLs (nazwane od głównego składnik białka PML). Ciałka PMLs są wielofunkcyjnymi organellami. Powstają w odpowiedzi na stres komórkowy wywołany infekcją wirusową [85], naprawą uszkodzeń DNA [86], stresem oksydacyjnym [87] i wieloma innymi czynnikami stresowymi [88]. Formowanie kondensatu odbywa się m.in. dzięki homotypowym oddziaływaniom PML [89]. Ważna dla tego procesu jest także sumoilacja trzech zachowanych ewolucyjnie reszt PML [90]. Ciałka PMLs stanowią doskonały przykład zależności pomiędzy formowaniem LLPS, a modyfikacjami potranslacyjnymi. Innym przykładem MLOs, formowanych w odpowiedzi na stres komórkowy, są cytoplazmatyczne granule stresowe (ang. stress granules). Ich formowanie odbywa się głównie w odpowiedzi na warunki stresowe [36]. Pierwszą linią obrony komórki na stres jest zahamowanie, a dokładniej przeprogramowanie translacji. Ma to na celu z jednej strony ograniczenie wydatków energetycznych, a z drugiej zapobieżenie pojawianiu się w komórce źle sfałdowanych białek [91]. W takiej sytuacji w cytoplazmie formowane są granule stresowe zawierające m.in. czynniki inicjacji translacji (eIF3, eIF4E, eIF4G i inne) [92,93], rybosomalną podjednostkę 40S [92] i poly(A)mRNA [26]. Ponadto skład granul stresowych różni się w zależności od rodzaju stresu i typu komórki [94]. Wyniki badań sugerują, że te MLOs, podobnie jak choćby opisane powyżej jąderka, posiadają niejednorodną strukturę. Składają się ze stabilnego rdzenia i dynamicznej otoczki, która może swobodnie wymieniać składniki z otoczeniem [95]. Co ciekawe, zauważono znaczne różnice w formowaniu granul stresowych tworzonych in vitro i w komórkach. Podczas gdy niska temperatura promuje ich formowanie in vitro [36], tak w przypadku badań na liniach komórkowych w niskich temperaturach granule stresowe tworzą się mniej wydajnie [96], co pokazuje jak ważne w tym obszarze badań są analizy w żywych układach. Co ciekawe, granule stresowe biorą udział nie tylko w potranskrypcyjnej regulacji ekspresji genów, lecz także chronią komórkę przed apoptozą [97, 98]. Ostatnio zaobserwowano też, że zaburzenia formowania, funkcjonowania, a także dysocjacji granul stresowych mają związek z rozwojem chorób, włączając amyloidozy obserwowane $\mathrm{w}$ przebiegu chorób neurodegeneracyjnych [36,99-101]. Z granulami stresowymi wiele wspólnego mają inne cytoplazmatyczne MLOs, czyli ciałka procesujące, zwane też ciałkami P (ang. processing bodies, P-bodies). Ciałka $\mathrm{P}$ także stanowią jeden $\mathrm{z}$ elementów odpowiedzi komórki na stres [102]. Tworzone są one z mRNA i białek odpowiedzialnych za represję translacji i rozpad mRNA [103,104], a główna różnica pomiędzy nimi a granulami stresowymi na poziome molekularnym związana jest z tym, iż w ciałkach procesujących nie występują czynniki inicjacji translacji.

Ten krótki opis wybranych komórkowych MLOs zawiera tylko niewielki wycinek wiedzy na temat ich różnorod- 


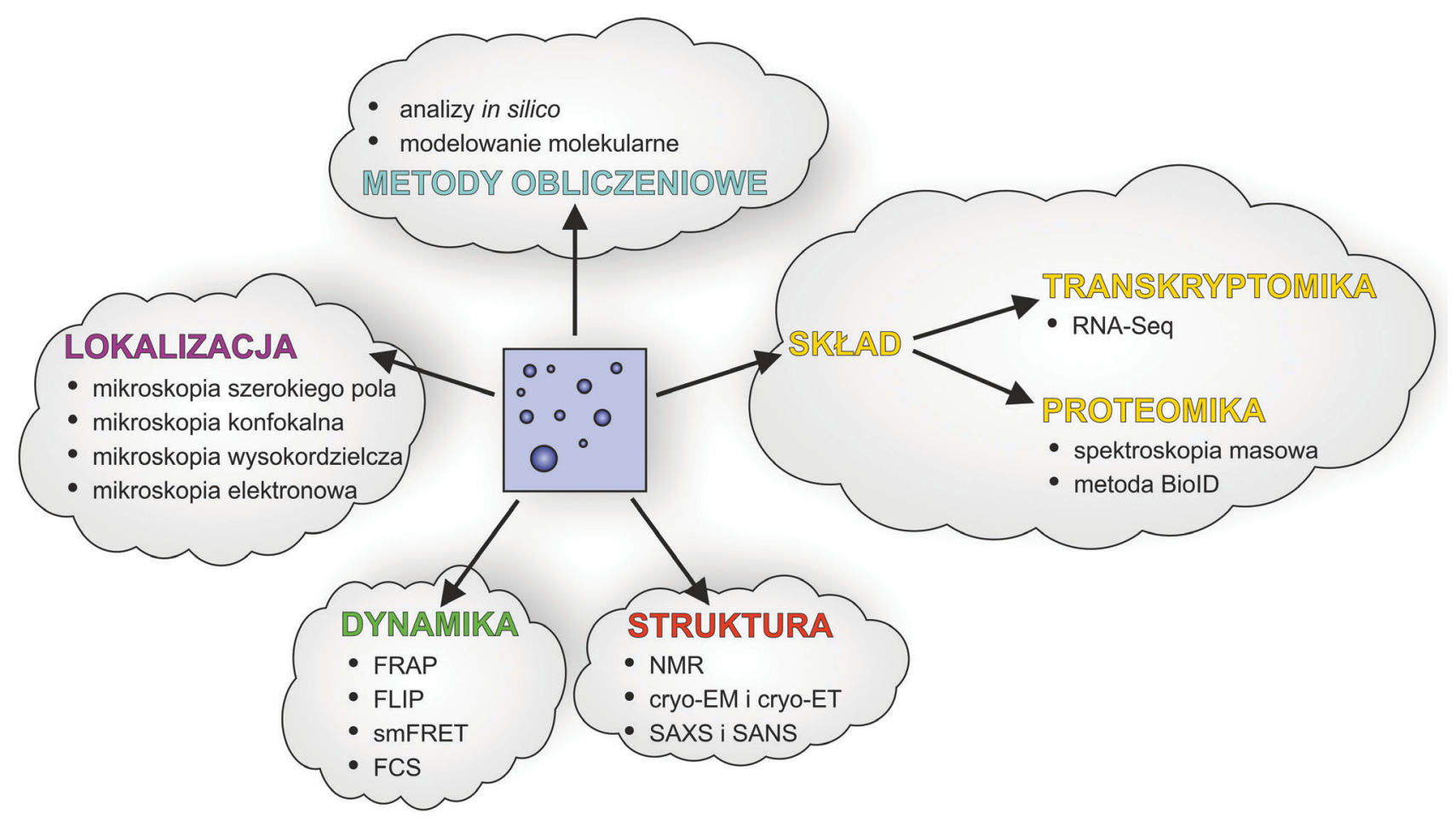

Rycina 4. Techniki wykorzystywane w badaniach MLOs. Techniki podzielono ze względu na badaną cechę MLOs bądź występujących w nich białek.

ności, lokalizacji i postulowanych funkcji. MLOs w istocie stanowią nierozłączny element żywej komórki. Choć są pozbawione fizycznej granicy w postaci błony lipidowej, to jednak są integralne i posiadają swoistą organizację strukturalną. Ich wspólną cechą jest sposób formowania, czyli na drodze LLPS, jednak poszczególne czynniki biofizyczne i biochemiczne inicjujące proces są różne dla różnych typów MLOs. MLOs stanowią wyzwanie dla współczesnej biologii molekularnej i biofizyki. Wymagają szczególnego podejścia eksperymentalnego i zastosowania odpowiedniego wachlarza technik.

\section{METODY BADAŃ MLOs}

Badania, których głównym polem zainteresowania są MLOs, dotyczą analiz w komórkach, a także w czystym układzie in vitro. Ponadto, w zależności od celu prowadzonych badań konieczne jest skupienie się na różnych właściwościach badanych MLOs, bądź występujących w nich białek, co wymaga zastosowania różnych technik (Ryc. 4). W tej części pracy zebrano i opisano techniki najczęściej stosowane do opisu MLOs.

\section{ANALIZA SKŁADU MLOs}

\section{METODY OBLICZENIOWE}

Tworzenie ciekłych kondensatów odbywa się za pośrednictwem różnych oddziaływań, w które angażowane są poszczególne reszty aminokwasowe. Jednak, zdolność danego białka do tworzenia kondensatów wynika nie tyle z jego składu aminokwasowego, co ze struktury pierwszorzędowej [22]. Jej szczegółowa analiza oraz przewidywanie struktury drugorzędowej mogą dostarczać informacji czy dane białko posiada potencjalnie zdolność do LLPS.
Jak przedstawiono powyżej, wiele białek biorących udział $\mathrm{w}$ LLPS posiada $\mathrm{w}$ swojej sekwencji pozbawione struktury drugorzędowej IDRs, często mające charakter LCS. Z tego też powodu, narzędzia służące do przewidywania nieuporządkowania wydają się być przydatne w kontekście wstępnych analiz in silico białek występujących w MLOs. Wśród takich narzędzi można wymienić IUPred (http:// iupred.enzim.hu) [105] czy służący do określania hydrofobowości, dystrybucji ładunku oraz stanu upakowania CIDER (http://pappulab.wustl.edu/CIDER/analysis) [106]. Ponadto, w ostatnim czasie pojawiły się również narzędzia dedykowane przewidywaniu tendencji danego białka do udziału w LLPS. Wykorzystują one bazy białek, dla których eksperymentalnie pokazano takie właściwości. Pierwszym $\mathrm{z}$ tych narzędzi jest algorytm catGRANULE (http:/ / service. tartaglialab.com/update_submission/257696/6e6862d1e1), który oblicza prawdopodobieństwo zdolności danego białka do udziału w LLPS $w$ oparciu o przewidywanie nieuporządkowania struktury, zdolności do wiązania RNA oraz występowania i długości specyficznych motywów w łańcuchu polipeptydowym [107]. Innym narzędziem jest predyktor skupiający się na oddziaływaniach $\pi-\pi$ (http:// abragam.med.utoronto.ca/ JFKlab/Software/psp.htm) [34]. Pomimo niewielkiej ilości takich predyktorów, i ich niezbyt dużej uniwersalności, oczywistym jest, że wraz z upływem czasu i kolejnymi odkryciami dotyczącymi białek obecnych w MLOs baza informacji o białkach będzie stale powiększana, a co za tym idzie tworzone predyktory będą coraz dokładniejsze. Jednocześnie z gwałtownym postępem w badaniach polimerów powstały modele teoretyczne, które opisują i przewidują rozpuszczalność i upakowanie łańcuchów polimerowych. Teoria Flory'ego-Huggins'a opisuje matematycznie konfiguracyjną entropię mieszania polimerów [108] zgodnie z poniższym równaniem: 


$$
\Delta S_{m}=-R\left[\frac{\phi_{A}}{n_{A}} \ln \phi_{A}+\frac{\phi_{B}}{n_{B}} \ln \phi_{B}\right]
$$

gdzie, $R$ - stała gazowa, $\phi$ - ułamek objętościowy składnika $A$ lub $B, n$ - liczba moli składnika $A$ lub $B$. Natomiast, zgodnie $\mathrm{z}$ tą teorią zmiana energii swobodnej wyraża się wzorem:

$$
\Delta G_{m}=R T\left[n_{A} \ln \phi_{A}+n_{B} \ln \phi_{B}+n_{A} \phi_{B} \chi_{A B}\right],
$$

gdzie $\chi$ - to tzw. współczynnik oddziaływania [109]. W oparciu o ten współczynnik, zwany również współczynnikiem oddziaływania Flory'ego-Huggins'a, możliwe jest określenie stopnia, $\mathrm{w}$ jakim polimer miesza się $\mathrm{z}$ rozpuszczalnikiem $[14,110]$. Biorąc pod uwagę, że organiczne polimery są bardzo podobne do białek, teoria ta została zastosowana między innymi do przewidywania zachowania fazowego dwuelementowego systemu składającego się z poli-SH3 (ang. poly-SRC homology 3 domain) i poly-PRM (ang. poly-Proline-rich motif) [5]. Z kolei Harmon i wsp. rozwinęli teorię Flory'ego-Huggins'a [14] bazując na teorii Flory'ego-Stockmayer'a [111] i modelu koralikowym opracowanym przez Semenov'a i Rubinstein'a [112] i wykorzystując modelowanie gruboziarniste oraz symulacje atomistyczne określili wpływ objętości solwatacyjnej łącznika na predyspozycje białka do kondensacji związanej bądź niezwiązanej z LLPS [113].

\section{TECHNIKI PROTEOMICZNE}

MLOs powstają $\mathrm{w}$ wyniku tworzenia sieci stabilizujących interakcji pomiędzy wieloma składnikami kondensatu $[43,114]$. Istotnym aspektem badań MLOs jest poznanie ich unikalnego składu. Do tego celu idealnie nadają się techniki bazujące na spektrometrii masowej. Jednakże MLOs są cieczami, które charakteryzują się bardzo dużą dynamiką, co znacznie utrudnia ich izolację. Pierwsze analizy proteomu MLOs zostały przeprowadzone przez Andersena i wsp. [115], którzy wykorzystali frakcjonowanie jądrowe oraz spektrometrię masową do scharakteryzowania proteomu jąderkowego. Dzięki wykorzystaniu 1D-, 2D-SDS-PAGE, MALDI-TOF oraz nano-elektrorozpylania udało się zidentyfikować 271 jąderkowych białek [115]. Późniejszy rozwój metod bazujących na spektrometrii masowej oraz rozwój analiz bioinformatycznych rozszerzył tę listę do 4500 białek [116]. Niestety, z uwagi na nietrwałość, nie wszystkie MLOs mogą zostać wyizolowane w nienaruszonej formie. Alternatywą może być zastosowanie metod pośrednich np. metody BioID. W metodzie tej interesujące białko jest znakowane zmodyfikowaną ligazą biotyny $\left(\operatorname{Bir}^{*}\right)$, która katalizuje biotynylację białek znajdujących się w odległości około 10 $\mathrm{nm}$, czyli takich, które najprawdopodobniej biorą udział w oddziaływaniu ze znakowanym białkiem [117]. Następnie, biotynylowane białka mogą być zidentyfikowane za pomocą spektrometrii masowej. Powyższą metodę zastosowali między Youn i wsp. w badaniach granuli stresowych i cialek P [118].

\section{ANALIZY STRUKTURALNE SKŁADNIKÓW MLOS}

\section{TECHNIKI STRUKTURALNE}

Jak wspomniano uprzednio, białka, które mają tendencję do udziału $\mathrm{w}$ procesie LLPS bardzo często posiadają nieuporządkowane LCSs, co znacznie utrudnia analizy ich struktury za pomocą typowych technik wykorzystywanych $w$ badaniach białek globularnych. Niska złożoność sekwencji powoduje, że $\mathrm{w}$ przypadku takich technik jak mikroskopia krioelektronowa (ang. cryo-electron microscopy, cryo-EM) czy magnetyczny rezonans jądrowy (ang. nuclear magnetic resonance, NMR) pojawiają się pewne ograniczenia. Niemniej jednak, w wielu badaniach MLOs postanowiono skorzystać z tych technik.

NMR

Obserwowane $\mathrm{w}$ technice NMR wartości przesunięcia chemicznego $(\delta)$ atomów specyficznych reszt aminokwasowych zawierają informacje o populacji regularnych struktur drugorzędowych (a-helis i $\beta$-struktur) i kłębka statystycznego oraz o lokalnym otoczeniu chemicznym [119]. Tym samym, zmiany wartości przesunięcia chemicznego (ang. chemical shift perturbation, CSP), wywołane na przykład wzmocnionym oddziaływaniem poszczególnych ugrupowań podczas LLPS, mogą być specyficznym wskazaniem miejsc takich oddziaływań oraz zmian konformacyjnych z nimi związanych [120,121]. Ponadto, możliwe jest również wyznaczenie tzw. drugorzędowego przesunięcia chemicznego $(\Delta \delta)$, które będąc różnicą pomiędzy eksperymentalną wartością $\delta$ oraz wystandaryzowaną wartością dla kłębka statystycznego informuje o tym, czy dany region ulega fałdowaniu [122]. Zastosowano to do analizy C-końcowego regionu białka TDP-43 (ang. TAR DNA binding protein 43) i wykazano, że w kondensacie region ten tworzy helisę [121]. Jądrowy efekt Overhausera (ang. nuclear Overhauser effect, NOE) polega na transferze polaryzacji $\mathrm{w}$ przestrzeni poprzez oddziaływanie dipol-dipol i jest zależny od wartości $\mathrm{r}^{-6}$, gdzie $\mathrm{r}$ to odległość pomiędzy dwoma jądrami atomów. Brady $i$ wsp. wykorzystali NOE, aby zbadać krótkodystansowe oddziaływania pomiędzy aminokwasami zasocjowanych LCSs helikazy DDX4 [123]. Pomimo, że nie udało się określić rezonansu indywidualnych aminokwasów z powodu niskiej złożoności sekwencji, wzmocnienie NOE obserwowano pomiędzy resztami Arg i Phe, co dostarczyło informacji na temat oddziaływań między aminokwasami będących podstawą tworzenia sieci molekularnej w trakcie LLPS przez to białko [123]. Komplementarną techniką do NOE jest pomiar wzmocnienia relaksacji paramagnetycznej (ang. paramagnetic relaxation enhancement, PRE). Zjawisko to występuje w przypadku oddziaływania dipol-dipol pomiędzy jądrem i niesparowanym elektronem znacznika posiadającego paramagnetyczny spin [124]. Technika ta została wykorzystana między innymi do pokazania, że międzycząsteczkowe oddziaływania pomiędzy fragmentami helikalnymi LCS TDP-43 prowadzą do LLPS [121]. W przypadku tej techniki należy mieć jednak na uwadze, że znakowanie białka może wpływać na jego strukturę i oddziaływanie z innymi białkami. 
Bardziej skomplikowane warianty techniki NMR mogą zostać również wykorzystane do analizy dynamiki poszczególnych składników MLOs. Metoda impulsowego gradientu pola magnetycznego (ang. pulse field gradient, PFG) jest wykorzystywana $\mathrm{w}$ celu określenia współczynników dyfuzji i jest przydatna w przypadku analizy złożonych mieszanin, ponieważ rezonans poszczególnych składników może zostać wyznaczony na podstawie wielkości cząsteczek $[35,43,123]$. Podczas eksperymentu PFG obserwowane jest tzw. zjawisko tłumienia intensywności, które zależy od współczynnika dyfuzji i czasu oraz gradientu pola magnetycznego. Małe tłumienie intensywności jest obserwowane dla dużych, wolno dyfundujących cząsteczek, a silne tłumienie intensywności obserwowane jest dla małych, szybko dyfundujących cząsteczek [125]. Używając tej techniki Mitrea $i$ wsp. zaobserwowali słabe odziaływania pomiędzy kwasowymi i zasadowymi IDRs NPM1, otrzymując tym samym informacje na temat mechanizmu oddziaływań międzycząsteczkowych NPM1, które prowadzą do LLPS [43]. Ponadto, w przypadku, gdy w następstwie LLPS tworzone są hydrożele, możliwe jest zastosowanie NMR ciała stałego (ang. solid state NMR, ssNMR) do zbadania ich właściwości strukturalnych i dynamicznych. Dannatt i wsp. pokazali, że białko wiążące jednoniciowe DNA z E. coli wykazuje tendencję do formowania hydrożeli in vitro [126]. Za pomocą techniki ssNMR udało się pokazać, że C-końcowy kwaśny motyw przejściowo oddziałuje z rowkiem wiążącym DNA i tym samym wyjaśniono podstawy tworzenia hydrożeli oraz mechanizm obserwowanej autoinhibicji [126].

\section{CRYO-EM ORAZ CRYO-ET}

Techniki cryo-EM oraz tomografia krioelektronowa (ang. cryo-electron tomography, cryo-ET) dostarczają wielu informacji strukturalnych w zakresie od Å do nm i mogą z powodzeniem być wykorzystywane do badania biomolekuł w ich naturalnym środowisku. Dzięki rejestracji wielu obrazów tej samej próbki pod różnym kątem i późniejszej odpowiedniej ich obróbki możliwe jest wygenerowanie obrazów 3D [127]. Niestety cryo-EM ma stosunkowo niewielkie zastosowanie w badaniach MLOs ze względu na wymaganą homogenność badanej próbki. $W$ najlepszym wypadku może ona być wykorzystana $w$ celu uzyskania informacji na temat oligomerów związanych z nukleacją i przejściem fazowym. Z kolei cryo-ET może być z powodzeniem wykorzystywane do badania strukturalnej organizacji biomolekuł wewnątrz MLOs utworzonych w wyniku LLPS. Technika ta została wykorzystana między innymi do scharakteryzowania żelo-podobnych kropli utworzonych przez białko Sup35. Wygenerowany obraz 3D pokazał dobrze zdefiniowaną, ale nieuporządkowaną, siatkę wzajemnie oddziałujących białek [128]. Ograniczeniem techniki cryo-ET jest grubość próbki i w przypadku próbek grubszych niż $300 \mathrm{~nm}$ uzyskiwane obrazy mogą być nieczytelne. Na szczęście, ze względu na ciągły intensywny rozwój technik cryo, powstają nowe metody przygotowywania próbek i tak, dzięki zastosowaniu techniki FIB (ang. focused beam milling) możliwe jest odpowiednie przygotowanie próbki o grubości 170 nm [129].

\section{MAŁOKĄTOWE ROZPRASZANIE}

Rozpraszanie promieniowania elektromagnetycznego może dostarczyć informacji na temat struktury i organizacji cząsteczek w roztworze w skali od $\AA$ do $\mu \mathrm{m}$ [130]. W metodzie tej wymagana jest jednak wysoka homogenność próbki, ponieważ $\mathrm{w}$ przeciwnym razie otrzymywane wyniki mogą być niejednoznaczne. Tym niemniej, metoda $z$ powodzeniem wykorzystywana jest $\mathrm{w}$ wielu badaniach dotyczących MLOs. Na podstawie uzyskanych krzywych rozpraszania $\mathrm{w}$ eksperymentach małokątowego rozpraszania promieni rentgenowskich (ang. small-angle X-ray scattering, SAXS) możliwe jest wyznaczenie promienia żyracji $\left(\mathrm{R}_{\mathrm{g}}\right)$, maksymalnej wielkości cząsteczek $\left(\mathrm{D}_{\mathrm{max}}\right)$, a także ich objętości [130]. Z kolei na podstawie wykresu Kratky'ego możliwe jest określenie kształtu cząsteczki [130]. Technika SAXS została między innymi wykorzystana $\mathrm{w}$ badaniach wielobiałkowych kompleksów powstających $\mathrm{w}$ procesie LLPS zawierających białko z domeną SH3 oraz ligand posiadający PRM [5]. Alternatywą dla SAXS jest małokątowe rozpraszanie neutronów (ang. small-angle neutron scattering, SANS) polegające na rejestrowaniu intensywności rozpraszania neutronów przez obecne w próbce jądra atomowe. W technice tej często stosuje się różne izotopy atomów, co pozwala na dokładniejsze analizy wielobiałkowych kompleksów. Technika taka została między innymi wykorzystana do pokazania, że nieuporządkowana domena nukleoporyny bogata w reszty Phe/Gly podczas oddziaływania $\mathrm{z}$ czynnikami transkrypcyjnymi ulega konformacyjnym rearanżacjom prowadzącym do zwiększenia jej promienia żyracji [131].

\section{OBRAZOWANIE ORAZ BADANIA LOKALIZACYJNE}

\section{MIKROSKOPIA ŚWIETLNA}

Mikroskopia świetlna jest techniką, która idealnie nadaje się do obrazowania MLOs w warunkach in vitro, włączając $\mathrm{w}$ to żywe i utrwalone komórki $[10,35,36]$. Biorąc pod uwagę to, że wprowadzanie zewnętrznych fluoroforów dostarcza pewnych trudności, o których będzie mowa pod koniec rozdziału, metody obrazowania, które tego nie wymagają wydają się dużo odpowiedniejsze. Dwie z najczęściej stosowanych metod to obrazowanie $\mathrm{z}$ wykorzystaniem kontrastu fazowego oraz obrazowanie z wykorzystaniem różniczkowego kontrastu interferencyjnego (ang. differential interference contrast, DIC) [132]. Opierają się one na różnicach współczynnika załamania światła lub różnicach w grubości struktur w próbce, które zmieniają fazę światła ulegającego dyfrakcji. Różnice fazowe są następnie przekształcane na różnice w intensywności, co skutkuje tym, że gęstsze obszary dają ciemniejsze obrazy [133]. Obrazowanie za pomocą DIC zostało wykorzystane na przykład do określenia granicznego stężenia formowania kropli przez białka DDX4 [35], LAF-1 [29], tau [134] oraz HP1a (ang. Heterochromatin protein 1 a) [135] posiadające motyw Arg-Gly-Gly, jak również do obrazowania w żywych komórkach gęstych MLOs, takich jak ciałka Cajala [136] czy jąderko [10]. Największą wadą metod niewykorzystujących fluoroforów jest to, że nie pozwalają one na śledzenie dynamiki poszczególnych składników MLOs. 


\section{MIKROSKOPIA FLUORESCENCYJNA}

Techniki mikroskopii fluorescencyjnej bazują na bezpośredniej detekcji fluoroforów dołączonych do badanego białka za pomocą metod chemicznych [137], genetycznych [138], immunologicznych [139], bądź enzymatycznych [140]. Poza występującymi na rynku znacznikami fluorescencyjnymi, które umożliwiają jedynie znakowanie badanego białka, dostępne są również znaczniki, które umożliwiają identyfikację specyficznych związków lub specyficznych struktur, takich jak na przykład $\beta$-struktury występujące we włóknach amyloidowych. Należy jednak podchodzić ostrożnie do stosowania poszczególnych znaczników fluorescencyjnych, gdyż ich obecność może w znaczący sposób wpływać na oddziaływanie pomiędzy znakowanymi cząsteczkami (np. dimeryzujące GFP) [141]. Tradycyjną mikroskopową techniką fluorescencyjną jest tzw. mikroskopia fluorescencyjna szerokiego pola (ang. wide-field fluorescence microscopy), w której fluorofory są wzbudzane w całym polu widzenia. Niestety wadą tej techniki jest to, że w przypadku zbyt grubych próbek (grubość powyżej $30 \mu \mathrm{m}$ ) fluorescencja pochodząca spoza płaszczyzny ogniskowej może pogarszać kontrast jak i rozdzielczość uzyskiwanego obrazu [142]. Wady tej pozbawiona jest mikroskopia konfokalna, w której światło pochodzące spoza płaszczyzny ogniskowej jest skutecznie blokowane przez dodatkową przesłonę [142]. Technika ta pozwala na znaczną poprawę kontrastu kosztem nieznacznego obniżenia intensywności sygnału. Warto nadmienić, że odpowiednie rejestrowanie obrazów w osi Z pozwala na rekonstrukcje obrazów 3D, a jeżeli obrazy są rejestrowanie $w$ odstępach czasu możliwe jest utworzenie obrazu 4D [137]. Rejestrowanie obrazów w czasie, w celu utworzenia obrazu 4D zostało zastosowane między innymi w badaniu dynamiki ciałek Cajala w nukleoplazmie [53]. Opisane powyżej techniki, w tradycyjnej formie są jednak stosowane jedynie do pozyskiwania danych dla stanów stacjonarnych. W przypadku, gdy celem jest zbadanie dynamiki oraz lepkosprężystych właściwości MLOs konieczne jest zastosowanie takich technik jak odzysk fluorescencji po fotoblaknięciu (ang. fluorescence recovery after photobleaching, FRAP) lub utrata fluorescencji w wyniku fotoblaknięcia (ang. fluorescence loss in photobleaching, FLIP). W obu tych technikach ROI (ang. region of interest) jest naświetlany światłem lasera o dużej intensywności, aby wygasić fluorescencję znajdujących się $\mathrm{w}$ tym regionie fluoroforów [137]. Następnie dyfuzja niewygaszonych i wygaszonych cząsteczek do i z ROI może być ilościowo oznaczona poprzez pomiar intensywności fluorescencji jako funkcji czasu [137]. Jako przykład można podać białko DDX4 obecne w MLOs, dla którego wyznaczono współczynnik dyfuzji oraz promień hydrodynamiczny stosując technikę FRAP, a otrzymane parametry były zgodne $\mathrm{z}$ tymi wyznaczonymi za pomoca NMR $[35,123]$. Kombinacja technik FRAP oraz FLIP została również wykorzystana przez Brangwynne i wsp. do zbadania dynamiki PGL-1 (ang. P-GranuLe abnormality) znakowanego GFP wewnątrz ciałek P w komórkach [9]. Kolejną bardzo ważną techniką fluorescencyjną, wykorzystywaną z powodzeniem w badaniach MLOs jest tzw. jednocząsteczkowy FRET (ang. single-molecule Förster Resonance Energy Transfer, smFRET). W tradycyjnej technice FRET wykorzystuje się dwa fluorofory, z których jeden jest donorem, a drugi akceptorem energii wzbudzenia. $W$ trakcie pomiaru donor jest wzbudzany falą o odpowiedniej długości. Jeśli akceptor znajduje się w odpowiedniej odległości, następuje transfer energii, dzięki czemu możliwe jest zaobserwowanie fluorescencji akceptora. Jednakże w przypadku tradycyjnej techniki FRET uzyskiwany sygnał jest pewną uśrednioną wartością pochodzącą od wielu cząsteczek. Niewątpliwą zaletą techniki smFRET jest to, że zamiast otrzymywania wartości, która jest średnią sygnałów, informacja jest uzyskiwana dla każdej cząsteczki osobno [143]. Elbaum-Grafinkle i wsp. badali oddziaływanie jednoniciowego RNA znakowanego znacznikami Cy3 i Cy5 z LAF-1. Za pomocą smFRET badacze pokazali, że gdy układ zbliżał się do granicy przejścia fazowego, oddziałujące kompleksy LAF-1 i RNA wykazywały różną dynamikę w fazie gęstej i fazie lekkiej ze znacznie zintensyfikowanymi fluktuacjami sprzyjającymi LLPS [29]. Z kolei Mitrea $i$ wsp. po zaznakowaniu NPM1 znacznikami AlexaFluor 488 i AlexaFluor 594 w IDR i na C-końcu domeny globularnej, pokazali, że siła jonowa, która hamuje w tym przypadku LLPS, powoduje konformacyjne wydłużenie IDR [43]. Spektroskopia korelacji fluorescencji (ang. fluorescence correlation spectroscopy, FCS) jest techniką, która pozwala na analizę dyfuzji cząsteczek poprzez pomiar fluktuacji intensywności fluorescencji znakowanej cząsteczki w małej objętości fokalnej (femtolitr) [144,145]. Technika ta pozwala na określenie współczynnika dyfuzji i stężenia fluorofora zarówno in vitro jak i in vivo, a także może służyć do obserwowania fluktuacji konformacyjnych oraz badania termodynamiki i kinetyki między- i wewnątrzcząsteczkowych oddziaływań [144,145]. Maharana i wsp. wykorzystali tę technikę do obserwowania dyfuzji białka FUS wewnątrz jądra i cytoplazmy [146].

Wszystkie z wymienionych powyżej technik fluorescencyjnych mogą być $\mathrm{z}$ powodzeniem stosowane $\mathrm{w}$ badaniach MLOs. Należy jednak pamiętać o kilku ograniczeniach. Należy mieć na uwadze, że choć utrwalanie żywych komórek stabilizuje oddziaływania międzycząsteczkowe oraz architekturę komórkową [147], to dynamika molekularna zostaje zakłócona. Z kolei znakowanie białek może w znaczący sposób wpływać na strukturę białka i w konsekwencji zmieniać dystrybucję docelowych składników w komórce [147]. W przypadku obrazowania żywych komórek należy mieć również na uwadze konieczność utrzymania optymalnych warunków hodowli komórkowej oraz minimalnej fototoksyczności podczas rejestracji obrazów jak również to, że ekspresja białek heterologicznych niekoniecznie musi odwzorowywać rzeczywisty poziom białek endogennych [147]. Wykorzystując mikroskopię konfokalną należy także mieć na uwadze pojawianie się ewentualnego fotouszkodzenia próbki lub fotowygaszania fluoroforów spowodowanych przez laser i powinno to być zminimalizowane, bądź uwzględnione w analizie obrazów. Z kolei w przypadku stosowania technik FRAP oraz FLIP należy pamiętać, że naświetlanie laserem wysokiej energii może prowadzić do występowania efektu fototoksycznego w żywych komórkach, zmieniać ich szlaki sygnałowe i tym samym prowadzić do zmiany właściwości oraz składu MLOs. W końcu w przypadku techniki smFRET należy pamiętać, że rozpraszanie światła przy długości fali powyżej $320 \mathrm{~nm}$ wynika ze zmętnienia próbki i należy to uwzględnić przy doborze odpowiednich znaczników fluorescencyjnych. 


\section{MIKROSKOPIA ELEKTRONOWA}

W technikach mikroskopii elektronowej (ang. electron microscopy, EM) wykorzystuje się wiązkę elektronów do naświetlania badanych próbek i otrzymywania obrazów

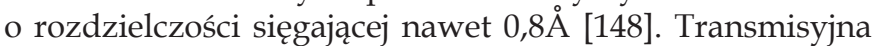
mikroskopia elektronowa (ang. transmission electron microscopy, TEM) z kolei, wykorzystuje znakowanie próbek metalami ciężkimi (np. uran, molibden) do obrazowania ultrastrukturalnych właściwości komórek [149]. TEM była wielokrotnie wykorzystywana do badania różnych MLOs, na przykład jąderek [150,151], cętek jądrowych [152], ciałek Cajala [136,153], czy granul RNP [154,155]. Z kolei Souquere i wsp. wiążąc próbki z koloidalnymi cząstkami złota pokrytymi specyficznymi przeciwciałami uzyskali informacje na temat składu oraz preferowanej lokalizacji jądrowej białka CRM1 (ang. Chromosomal maintenance 1) [156]. Największą wadą technik mikroskopii elektronowej jest to, że konieczne jest utrwalenie oraz specyficzne przygotowanie próbki, co automatycznie wyklucza możliwość obrazowania procesów biologicznych w czasie rzeczywistym.

\section{INNE TECHNIKI POMOCNE W BADANIACH MLOs}

Techniki, które zostały wymienione powyżej to tylko wybrane z wielu, które można wykorzystywać do badań MLOs. Poza tymi opisanymi, można jeszcze wymienić takie jak techniki opierające się na rozpraszaniu promieniowania elektromagnetycznego. Z tej grupy bardzo często stosuje się metody polegające na pomiarze zmętnienia próbki. Pomiar ten wykonuje się mierząc absorbancję próbki przy długości fali poza zakresem odpowiadającym widmu absorpcji białka (zazwyczaj $\lambda=320 \mathrm{~nm}$ lub $\lambda=600 \mathrm{~nm}$ ) $[45,48,121]$. Następnie, dzięki odpowiedniej manipulacji warunkami eksperymentu, możliwe jest wyznaczenie granicznego stężenia czy temperatury, przy których zachodzi proces separacji faz. Należy jednak pamiętać, że wzrost zmętnienia może wynikać również z powstawania agregatów białkowych, dlatego warto łączyć analizę zmętnienia próbki z techniką, mikroskopową np. DIC. Innymi metodami wykorzystującymi rozpraszanie promieniowania elektromagnetycznego, które się powszechnie stosuje w badaniach MLOs są: dynamiczne rozpraszanie światła (ang. dynamic light scattering, DLS), statyczne rozpraszanie światła (ang. static light scattering, DLS) czy wielokątowe rozpraszanie światła (ang. multi-angle light scattering, MALS), które wykorzystuje się między innymi do określania wielkości jak i kształtów białek [130]. Ponadto powszechnie wykorzystywane są metody mające na celu kompleksowe badania transkryptomiczne ze względu na powszechną obecność specyficznych sekwencji RNA w MLOs. Wśród tych technik można wymienić między innymi połączenie techniki RNA-Seq z techniką FISH (ang. fluorescence in situ hybridization) [157-159]. Ponadto należy również wspomnieć o niektórych technikach mikroskopii wysokorozdzielczej, takich jak SIM (ang. structured illumination microscopy), STORM (ang. stochastic optical reconstruction microscopy) czy LLSM (ang. lattice light-sheet microscopy), które dzięki połączeniu danych optycznych z analizami matematycznymi są w stanie dostarczyć obrazy o rozdzielczości nawet 10-krotnie większej niż limit dyfrakcji [160].

\section{PODSUMOWANIE}

MLOs sa różnorodynymi organellami komórkowymi, jednak w ich formowaniu i funkcjonowaniu można doszukać się pewnych prawidłowości. Wiedza odnośnie ich składu, sposobu formowania czy funkcji w ostatnich latach poszerza się, jednak wciąż wiele aspektów pozostaje nierozpoznanych i wymaga dalszych badań. Niejasny pozostaje na przykład związek pomiędzy zaburzeniami funkcji niektórych MLOs a rozwojem chorób neurodegeneracyjnych. Badania MLOs wymagają stosowania specjalnego zestawu technik eksperymentalnych. Sporo technik stosowanych w biochemii białek czy biologii strukturalnej napotyka na pewne ograniczenia uniemożliwiające ich pełne wykorzystanie do badań MLOs. Wynika to bardzo często z nieuporządkowanej natury LCSs oraz z dużej dynamiki składu kondensatu, który ulega zmianom w odpowiedzi na zmieniające się warunki fizykochemiczne otoczenia. W związku z tym, w przypadku badań MLOs, konieczne jest zastosowanie kompleksowej analizy z wykorzystaniem wielu różnych technik, z których każda pozwoli na zbadanie innego aspektu MLO. Jedynie w taki sposób można określić skład, strukturę, lokalizację MLOs, a także takie ich parametry reologiczne jak lepkość czy napięcie powierzchniowe. Ponadto, ciągły rozwój metod in silico napawa nadzieją, że w niedalekiej przyszłości pojawią się kolejne i coraz dokładniejsze metody pozwalające na analizy MLOs oraz białek w nich występujących.

\section{LITERATURA}

1. Gould SB (2018) Membranes and evolution. Curr Biol 28: R381-R385

2. Boeynaems S, Alberti S, Fawzi NL, Mittag T, Polymenidou M, Rousseau F, Schymkowitz J, Shorter J, Wolozin B, Van Den Bosch L, Tompa P, Fuxreiter M (2018) Protein Phase Separation: A New Phase in Cell Biology. Trends Cell Biol 28: 420-435

3. Yoo H, Triandafillou C, Drummond DA (2019) Cellular sensing by phase separation: Using the process, not just the products. J Biol Chem 294: 7151-7159

4. Sawyer IA, Bartek J, Dundr M (2019) Phase separated microenvironments inside the cell nucleus are linked to disease and regulate epigenetic state, transcription and RNA processing. Semin Cell Dev Biol 90: 94-103

5. Li P, Banjade S, Cheng HC, Kim S, Chen B, Guo L, Llaguno M, Hollingsworth JV, King DS, Banani SF, Russo PS, Jiang QX, Nixon BT, Rosen MK (2012) Phase transitions in the assembly of multivalent signalling proteins. Nature 483: 336-340

6. Shin Y, Brangwynne CP (2017) Liquid phase condensation in cell physiology and disease. Science 357: 1-11

7. Aguilera-Gomez A, Rabouille C (2017) Membrane-bound organelles versus membrane-less compartments and their control of anabolic pathways in Drosophila. Dev Biol 428: 310-317

8. Gomes E, Shorter J (2019) The molecular language of membraneless organelles. J Biol Chem 294: 7115-7127

9. Brangwynne CP, Eckmann CR, Courson DS, Rybarska A, Hoege C, Gharakhani J, Julicher F, Hyman AA (2009) Germline P granules are liquid droplets that localize by controlled dissolution/condensation. Science 324: 1729-1732

10. Brangwynne CP, Mitchison TJ, Hyman AA (2011) Active liquid-like behavior of nucleoli determines their size and shape in Xenopus laevis oocytes. Proc Natl Acad Sci U S A 108: 4334-4339

11. Hyman AA, Weber CA, Julicher F (2014) Liquid-liquid phase separation in biology. Annu Rev Cell Dev Biol 30: 39-58

12. Brangwynne CP (2013) Phase transitions and size scaling of membrane-less organelles. J Cell Biol 203: 875-881 
13. Huggins ML (1942) Some properties of solutions of long-chain compounds. J Phys Chem-Us 46: 151-158

14. Flory PJ, Krigbaum WR (1951) Thermodynamics of High Polymer Solutions. Ann Rev Phys Chem 2: 383-402

15. Brangwynne CP, Tompa P, Pappu RV (2015) Polymer physics of intracellular phase transitions. Nat Phys 11: 899-904

16. Posey AE, Holehouse AS, Pappu RV (2018) Phase Separation of Intrinsically Disordered Proteins. Methods Enzymol 611: 1-30

17. Martin EW, Mittag T (2018) Relationship of Sequence and Phase Separation in Protein Low-Complexity Regions. Biochemistry 57: 24782487

18. Alberti S, Gladfelter A, Mittag T (2019) Considerations and Challenges in Studying Liquid-Liquid Phase Separation and Biomolecular Condensates. Cell 176: 419-434

19. Jekely G (2014) Origin and evolution of the self-organizing cytoskeleton in the network of eukaryotic organelles. Cold Spring Harb Perspect Biol 6: 1-20

20. Itakura AK, Futia RA, Jarosz DF (2018) It Pays To Be in Phase. Biochemistry 57: 2520-2529.

21. Alberti S (2017) Phase separation in biology. Curr Biol 27: R1097-R1102

22. Lin YH, Forman-Kay JD, Chan HS (2018) Theories for Sequence-Dependent Phase Behaviors of Biomolecular Condensates. Biochemistry 57: 2499-2508

23. Patel A, Lee HO, Jawerth L, Maharana S, Jahnel M, Hein MY, Stoynov S, Mahamid J, Saha S, Franzmann TM, Pozniakovski A, Poser I, Maghelli N, Royer LA, Weigert M, Myers EW, Grill S, Drechsel D, Hyman AA, Alberti S (2015) A Liquid-to-Solid Phase Transition of the ALS Protein FUS Accelerated by Disease Mutation. Cell 162: 1066-1077

24. Alberti S, Dormann D (2019) Liquid-Liquid Phase Separation in Disease. Annu Rev Genet 53: 171-194

25. Banani SF, Rice AM, Peeples WB, Lin Y, Jain S, Parker R, Rosen MK (2016) Compositional Control of Phase-Separated Cellular Bodies. Cell 166: 651-663

26. Buchan JR, Parker R (2009) Eukaryotic stress granules: the ins and outs of translation. Mol Cell 36: 932-941

27. Uversky VN, Kuznetsova IM, Turoverov KK, Zaslavsky B (2015) Intrinsically disordered proteins as crucial constituents of cellular aqueous two phase systems and coacervates. FEBS Lett 589: 15-22

28. Wang JT, Smith J, Chen BC, Schmidt H, Rasoloson D, Paix A, Lambrus BG, Calidas D, Betzig E, Seydoux G (2014) Regulation of RNA granule dynamics by phosphorylation of serine-rich, intrinsically disordered proteins in C. elegans. Elife 3: 1-23

29. Elbaum-Garfinkle S, Kim Y, Szczepaniak K, Chen CC, Eckmann CR, Myong S, Brangwynne CP (2015) The disordered P granule protein LAF-1 drives phase separation into droplets with tunable viscosity and dynamics. Proc Natl Acad Sci U S A 112: 7189-7194

30. Coletta A, Pinney JW, Solis DY, Marsh J, Pettifer SR, Attwood TK (2010) Low-complexity regions within protein sequences have position-dependent roles. BMC Syst Biol 4: 43

31. Reichheld SE, Muiznieks LD, Keeley FW, Sharpe S (2017) Direct observation of structure and dynamics during phase separation of an elastomeric protein. Proc Natl Acad Sci U S A 114: E4408-E4415

32. Lin Y, Currie SL, Rosen MK (2017) Intrinsically disordered sequences enable modulation of protein phase separation through distributed tyrosine motifs. J Biol Chem 292: 19110-19120

33. Denning DP, Patel SS, Uversky V, Fink AL, Rexach M (2003) Disorder in the nuclear pore complex: the FG repeat regions of nucleoporins are natively unfolded. Proc Natl Acad Sci U S A 100: 2450-2455

34. Vernon RM, Chong PA, Tsang B, Kim TH, Bah A, Farber P, Lin H, Forman-Kay JD (2018) Pi-Pi contacts are an overlooked protein feature relevant to phase separation. Elife 7: 1-48

35. Nott TJ, Petsalaki E, Farber P, Jervis D, Fussner E, Plochowietz A, Craggs TD, Bazett-Jones DP, Pawson T, Forman-Kay JD, Baldwin AJ (2015) Phase transition of a disordered nuage protein generates environmentally responsive membraneless organelles. Mol Cell 57: 936947
36. Molliex A, Temirov J, Lee J, Coughlin M, Kanagaraj AP, Kim HJ, Mittag T, Taylor JP (2015) Phase separation by low complexity domains promotes stress granule assembly and drives pathological fibrillization. Cell 163: 123-133

37. Hughes MP, Sawaya MR, Boyer DR, Goldschmidt L, Rodriguez JA, Cascio D, Chong L, Gonen T, Eisenberg DS (2018) Atomic structures of low-complexity protein segments reveal kinked beta sheets that assemble networks. Science 359: 698-701

38. Schmidt HB, Gorlich D (2015) Nup98 FG domains from diverse species spontaneously phase-separate into particles with nuclear pore-like permselectivity. Elife 4: e04251

39. Latonen L (2019) Phase-to-Phase With Nucleoli - Stress Responses, Protein Aggregation and Novel Roles of RNA. Front Cell Neurosci 13: 151

40. Shaw P, Brown J (2012) Nucleoli: composition, function, and dynamics. Plant Physiol 158: 44-51

41. Goodfellow SJ, Zomerdijk JC (2013) Basic mechanisms in RNA polymerase I transcription of the ribosomal RNA genes. Subcell Biochem 61: $211-236$

42. Bassler J, Hurt E (2019) Eukaryotic Ribosome Assembly. Annu Rev Biochem 88: 281-306

43. Mitrea DM, Cika JA, Stanley CB, Nourse A, Onuchic PL, Banerjee PR, Phillips AH, Park CG, Deniz AA, Kriwacki RW (2018) Self-interaction of NPM1 modulates multiple mechanisms of liquid-liquid phase separation. Nat Commun 9: 842

44. Frottin F, Schueder F, Tiwary S, Gupta R, Korner R, Schlichthaerle T, Cox J, Jungmann R, Hartl FU, Hipp MS (2019) The nucleolus functions as a phase-separated protein quality control compartment. Science 365: 342-347

45. Feric M, Vaidya N, Harmon TS, Mitrea DM, Zhu L, Richardson TM, Kriwacki RW, Pappu RV, Brangwynne CP (2016) Coexisting Liquid Phases Underlie Nucleolar Subcompartments. Cell 165: 1686-1697

46. Biggiogera M, Burki K, Kaufmann SH, Shaper JH, Gas N, Amalric F, Fakan S (1990) Nucleolar Distribution of Proteins B23 and Nucleolin in Mouse Preimplantation Embryos as Visualized by Immunoelectron Microscopy. Development 110: 1263-1270

47. Lee HH, Kim HS, Kang JY, Lee BI, Ha JY, Yoon HJ, Lim SO, Jung G, Suh SW (2007) Crystal structure of human nucleophosmin-core reveals plasticity of the pentamer-pentamer interface. Proteins 69: 672-678

48. Mitrea DM, Cika JA, Guy CS, Ban D, Banerjee PR, Stanley CB, Nourse A, Deniz AA, Kriwacki RW (2016) Nucleophosmin integrates within the nucleolus via multi-modal interactions with proteins displaying R-rich linear motifs and rRNA. Elife 5: e13571

49. Ramon y Cajal S (1903) Un sencillo metodo de coloracion seletiva del reticulo protoplasmatico y sus efectos en los diversos organos nerviosos de vertebrados e invertebrados. Trab. Lab. Invest. Biol 2: 129-221

50. Raska I, Andrade LEC, Ochs RL, Chan EKL, Chang CM, Roos G, Tan EM (1991) Immunological and Ultrastructural Studies of the Nuclear Coiled Body with Autoimmune Antibodies. Experimental Cell Research 195: 27-37

51. Trinkle-Mulcahy L, Sleeman JE (2017) The Cajal body and the nucleolus: "In a relationship" or "It's complicated"? RNA Biol 14: 739-751

52. Sleeman J, Lyon CE, Platani M, Kreivi JP, Lamond AI (1998) Dynamic interactions between splicing snRNPs, coiled bodies and nucleoli revealed using snRNP protein fusions to the green fluorescent protein. Exp Cell Res 243: 290-304

53. Platani M, Goldberg I, Swedlow JR, Lamond AI (2000) In vivo analysis of Cajal body movement, separation, and joining in live human cells. J Cell Biol 151: 1561-1574

54. Meier UT (2017) RNA modification in Cajal bodies. RNA Biol 14: 693700

55. Stanek D (2017) Cajal bodies and snRNPs - friends with benefits. RNA Biol 14: 671-679

56. Wang Q, Sawyer IA, Sung MH, Sturgill D, Shevtsov SP, Pegoraro G, Hakim O, Baek S, Hager GL, Dundr M (2016) Cajal bodies are linked to genome conformation. Nat Commun 7: 10966 
57. Sawyer IA, Sturgill D, Sung MH, Hager GL, Dundr M (2016) Cajal body function in genome organization and transcriptome diversity. Bioessays 38: 1197-1208

58. Misteli T, Caceres JF, Spector DL (1997) The dynamics of a pre-mRNA splicing factor in living cells. Nature 387: 523-527

59. Lamond AI, Spector DL (2003) Nuclear speckles: a model for nuclear organelles. Nat Rev Mol Cell Biol 4: 605-612

60. Galganski L, Urbanek MO, Krzyzosiak WJ (2017) Nuclear speckles: molecular organization, biological function and role in disease. Nucleic Acids Res 45: 10350-10368

61. Phair RD, Misteli T (2000) High mobility of proteins in the mammalian cell nucleus. Nature 404: 604-609

62. Mintz PJ, Patterson SD, Neuwald AF, Spahr CS, Spector DL (1999) Purification and biochemical characterization of interchromatin granule clusters. EMBO J 18: 4308-4320

63. Schuettengruber B, Bourbon HM, Di Croce L, Cavalli G (2017) Genome Regulation by Polycomb and Trithorax: 70 Years and Counting. Cell 171: 34-57

64. Trojer P, Reinberg D (2007) Facultative heterochromatin: is there a distinctive molecular signature? Mol Cell 28: 1-13

65. Cao R, Wang L, Wang H, Xia L, Erdjument-Bromage H, Tempst P, Jones RS, Zhang Y (2002) Role of histone H3 lysine 27 methylation in Polycomb-group silencing. Science 298: 1039-1043

66. Kalb R, Latwiel S, Baymaz HI, Jansen PW, Muller CW, Vermeulen M, Muller J (2014) Histone H2A monoubiquitination promotes histone H3 methylation in Polycomb repression. Nat Struct Mol Biol 21: 569571

67. Blackledge NP, Farcas AM, Kondo T, King HW, McGouran JF, Hanssen LL, Ito S, Cooper S, Kondo K, Koseki Y, Ishikura T, Long HK, Sheahan TW, Brockdorff N, Kessler BM, Koseki H, Klose RJ (2014) Variant PRC1 complex-dependent H2A ubiquitylation drives PRC2 recruitment and polycomb domain formation. Cell 157: 1445-1459

68. Pirrotta V, Li HB (2012) A view of nuclear Polycomb bodies. Curr Opin Genet Dev 22: 101-109

69. Kundu S, Ji F, Sunwoo H, Jain G, Lee JT, Sadreyev RI, Dekker J, Kingston RE (2017) Polycomb Repressive Complex 1 Generates Discrete Compacted Domains that Change during Differentiation. Mol Cell 65: 432-446 e435

70. Tatavosian R, Kent S, Brown K, Yao T, Duc HN, Huynh TN, Zhen CY, Ma B, Wang H, Ren X (2019) Nuclear condensates of the Polycomb protein chromobox 2 (CBX2) assemble through phase separation. J Biol Chem 294: 1451-1463

71. Hnisz D, Shrinivas K, Young RA, Chakraborty AK, Sharp PA (2017) A Phase Separation Model for Transcriptional Control. Cell 169: 13-23

72. Chen X, Xu H, Yuan P, Fang F, Huss M, Vega VB, Wong E, Orlov YL, Zhang W, Jiang J, Loh YH, Yeo HC, Yeo ZX, Narang V, Govindarajan KR, Leong B, Shahab A, Ruan Y, Bourque G, Sung WK, Clarke $\mathrm{ND}$, Wei CL, Ng HH (2008) Integration of external signaling pathways with the core transcriptional network in embryonic stem cells. Cell 133: 1106-1117

73. Mansour MR, Abraham BJ, Anders L, Berezovskaya A, Gutierrez A, Durbin AD, Etchin J, Lawton L, Sallan SE, Silverman LB, Loh ML, Hunger SP, Sanda T, Young RA, Look AT (2014) Oncogene regulation. An oncogenic super-enhancer formed through somatic mutation of a noncoding intergenic element. Science 346: 1373-1377

74. Brown JD, Lin CY, Duan Q, Griffin G, Federation A, Paranal RM, Bair S, Newton G, Lichtman A, Kung A, Yang T, Wang H, Luscinskas FW, Croce K, Bradner JE, Plutzky J (2014) NF-kappaB directs dynamic super enhancer formation in inflammation and atherogenesis. Mol Cell 56: $219-231$

75. Loven J, Hoke HA, Lin CY, Lau A, Orlando DA, Vakoc CR, Bradner JE, Lee TI, Young RA (2013) Selective inhibition of tumor oncogenes by disruption of super-enhancers. Cell 153: 320-334

76. Sabari BR, Dall'Agnese A, Boija A, Klein IA, Coffey EL, Shrinivas K, Abraham BJ, Hannett NM, Zamudio AV, Manteiga JC, Li CH, Guo YE, Day DS, Schuijers J, Vasile E, Malik S, Hnisz D, Lee TI, Cisse, II, Roeder RG, Sharp PA, Chakraborty AK, Young RA (2018) Coactivator condensation at super-enhancers links phase separation and gene control. Science 361: eaar3958

77. Soltys K, Ozyhar A (2020) Ordered structure-forming properties of the intrinsically disordered $\mathrm{AB}$ region of $\mathrm{hRXRgamma}$ and its ability to promote liquid-liquid phase separation. J Steroid Biochem Mol Biol 198: 105571

78. Tarczewska A, Greb-Markiewicz B (2019) The Significance of the Intrinsically Disordered Regions for the Functions of the bHLH Transcription Factors. Int J Mol Sci 20: 5306

79. Lu H, Yu D, Hansen AS, Ganguly S, Liu R, Heckert A, Darzacq X, Zhou Q (2018) Phase-separation mechanism for C-terminal hyperphosphorylation of RNA polymerase II. Nature 558: 318-323

80. Lu Y, Wu TT, Gutman O, Lu HS, Zhou Q, Henis YI, Luo KX (2020) Phase separation of TAZ compartmentalizes the transcription machinery to promote gene expression. Nat Cell Biol 22: 453-464

81. Ciechanover A, DiGiuseppe JA, Bercovich B, Orian A, Richter JD, Schwartz AL, Brodeur GM (1991) Degradation of nuclear oncoproteins by the ubiquitin system in vitro. Proc Natl Acad Sci U S A 88: 139143

82. Palombella VJ, Rando OJ, Goldberg AL, Maniatis T (1994) The Ubiquitin-Proteasome Pathway Is Required for Processing the Nf-Kappa-B1 Precursor Protein and the Activation of Nf-Kappa-B. Cell 78: 773-785

83. Kim TK, Maniatis T (1996) Regulation of interferon-gamma-activated STAT1 by the ubiquitin-proteasome pathway. Science 273: 1717-1719

84. Lafarga M, Berciano MT, Pena E, Mayo I, Castano JG, Bohmann D, Rodrigues JP, Tavanez JP, Carmo-Fonseca M (2002) Clastosome: a subtype of nuclear body enriched in 195 and $20 S$ proteasomes, ubiquitin and protein substrates of proteasome. Mol Biol Cell 13: 2771-2782

85. Everett RD (2006) Interactions between DNA viruses, ND10 and the DNA damage response. Cell Microbiol 8: 365-374

86. Dellaire G, Ching RW, Ahmed K, Jalali F, Tse KC, Bristow RG, Bazett-Jones DP (2006) Promyelocytic leukemia nuclear bodies behave as DNA damage sensors whose response to DNA double-strand breaks is regulated by NBS1 and the kinases ATM, Chk2, and ATR. J Cell Biol 175: 55-66

87. Yamada M, Sato T, Shimohata T, Hayashi S, Igarashi S, Tsuji S, Takahashi $\mathrm{H}$ (2001) Interaction between neuronal intranuclear inclusions and promyelocytic leukemia protein nuclear and coiled bodies in CAG repeat diseases. Am J Pathol 159: 1785-1795

88. Lallemand-Breitenbach V, de The H (2010) PML nuclear bodies. Cold Spring Harb Perspect Biol 2: a000661

89. Huang SY, Naik MT, Chang CF, Fang PJ, Wang YH, Shih HM, Huang TH (2014) The B-box 1 dimer of human promyelocytic leukemia protein. J Biomol NMR 60: 275-281

90. Shen TH, Lin HK, Scaglioni PP, Yung TM, Pandolfi PP (2006) The mechanisms of PML-nuclear body formation. Mol Cell 24: 331-339

91. Liu B, Qian SB (2014) Translational reprogramming in cellular stress response. Wiley Interdiscip Rev RNA 5: 301-315

92. Kimball SR, Horetsky RL, Ron D, Jefferson LS, Harding HP (2003) Mammalian stress granules represent sites of accumulation of stalled translation initiation complexes. Am J Physiol Cell Physiol 284: C273284

93. Kedersha N, Stoecklin G, Ayodele M, Yacono P, Lykke-Andersen J, Fritzler MJ, Scheuner D, Kaufman RJ, Golan DE, Anderson P (2005) Stress granules and processing bodies are dynamically linked sites of mRNP remodeling. J Cell Biol 169: 871-884

94. Markmiller S, Soltanieh S, Server KL, Mak R, Jin W, Fang MY, Luo EC, Krach F, Yang D, Sen A, Fulzele A, Wozniak JM, Gonzalez DJ, Kankel MW, Gao FB, Bennett EJ, Lecuyer E, Yeo GW (2018) Context-Dependent and Disease-Specific Diversity in Protein Interactions within Stress Granules. Cell 172: 590-604 e513

95. Jain S, Wheeler JR, Walters RW, Agrawal A, Barsic A, Parker R (2016) ATPase-Modulated Stress Granules Contain a Diverse Proteome and Substructure. Cell 164: 487-498

96. Wheeler JR, Matheny T, Jain S, Abrisch R, Parker R (2016) Distinct stages in stress granule assembly and disassembly. Elife 5: e18413 
97. Arimoto K, Fukuda H, Imajoh-Ohmi S, Saito H, Takekawa M (2008) Formation of stress granules inhibits apoptosis by suppressing stress-responsive MAPK pathways. Nat Cell Biol 10: 1324-1332

98. Takahashi M, Higuchi M, Matsuki H, Yoshita M, Ohsawa T, Oie M, Fujii M (2013) Stress granules inhibit apoptosis by reducing reactive oxygen species production. Mol Cell Biol 33: 815-829

99. Wolozin B (2012) Regulated protein aggregation: stress granules and neurodegeneration. Mol Neurodegener 7: 56

100. Wolozin B, Ivanov P (2019) Stress granules and neurodegeneration. Nat Rev Neurosci 20: 649-666

101. Zhang K, Daigle JG, Cunningham KM, Coyne AN, Ruan K, Grima JC, Bowen KE, Wadhwa H, Yang P, Rigo F, Taylor JP, Gitler AD, Rothstein JD, Lloyd TE (2018) Stress Granule Assembly Disrupts Nucleocytoplasmic Transport. Cell 173: 958-971 e917

102. Schutz S, Noldeke ER, Sprangers R (2017) A synergistic network of interactions promotes the formation of in vitro processing bodies and protects mRNA against decapping. Nucleic Acids Res 45: 69116922

103. Parker R, Sheth U (2007) P bodies and the control of mRNA translation and degradation. Mol Cell 25: 635-646

104. Decker CJ, Parker R (2012) P-bodies and stress granules: possible roles in the control of translation and mRNA degradation. Cold Spring Harb Perspect Biol 4: a012286

105. Dosztanyi Z, Csizmok V, Tompa P, Simon I (2005) IUPred: web server for the prediction of intrinsically unstructured regions of proteins based on estimated energy content. Bioinformatics 21: 3433-3434

106. Das RK, Pappu RV (2013) Conformations of intrinsically disordered proteins are influenced by linear sequence distributions of oppositely charged residues. Proc Natl Acad Sci U S A 110: 13392-13397

107. Bolognesi B, Lorenzo Gotor N, Dhar R, Cirillo D, Baldrighi M, Tartaglia GG, Lehner B (2016) A Concentration-Dependent Liquid Phase Separation Can Cause Toxicity upon Increased Protein Expression. Cell Rep 16: 222-231

108. Flory PJ (1956) Statistical Thermodynamics of Semi-Flexible Chain Molecules. Proceedings of the Royal Society of London. Series A, Mathematical and Physical Sciences 234: 60-73

109. Kobayashi S, Müllen K (2019) Encyclopedia of Polymeric Nanomaterials, Springer Berlin Heidelberg Imprint, Springer, Berlin, Heidelberg

110. Gennes P-Gd (2005) Scaling concepts in polymer physics, Cornell Univ. Press, Ithaca, NY

111. Flory PJ (1941) Molecular size distribution in three dimensional polymers. I. Gelation. J Am Chem Soc 63: 3083-3090

112. Rubinstein M, Semenov AN (2001) Dynamics of entangled solutions of associating polymers. Macromolecules 34: 1058-1068

113. Harmon TS, Holehouse AS, Rosen MK, Pappu RV (2017) Intrinsically disordered linkers determine the interplay between phase separation and gelation in multivalent proteins. Elife 6: e30294

114. Weber SC, Brangwynne CP (2015) Inverse size scaling of the nucleolus by a concentration-dependent phase transition. Curr Biol 25: 641-646

115. Andersen JS, Lyon CE, Fox AH, Leung AK, Lam YW, Steen H, Mann M, Lamond AI (2002) Directed proteomic analysis of the human nucleolus. Curr Biol 12: 1-11

116. Rosner M, Schipany K, Hengstschlager M (2013) Merging high-quality biochemical fractionation with a refined flow cytometry approach to monitor nucleocytoplasmic protein expression throughout the unperturbed mammalian cell cycle. Nat Protoc 8: 602-626

117. Kim DI, Birendra KC, Zhu W, Motamedchaboki K, Doye V, Roux KJ (2014) Probing nuclear pore complex architecture with proximity-dependent biotinylation. Proc Natl Acad Sci U S A 111: E2453-2461

118. Youn JY, Dunham WH, Hong SJ, Knight JDR, Bashkurov M, Chen GI, Bagci H, Rathod B, MacLeod G, Eng SWM, Angers S, Morris Q, Fabian M, Cote JF, Gingras AC (2018) High-Density Proximity Mapping Reveals the Subcellular Organization of mRNA-Associated Granules and Bodies. Mol Cell 69: 517-532 e511
119. Holzgrabe U, Wawer I, Diehl B (2008) NMR spectroscopy in pharmaceutical analysis, Elsevier, Oxford

120. Burke KA, Janke AM, Rhine CL, Fawzi NL (2015) Residue-by-Residue View of In Vitro FUS Granules that Bind the C-Terminal Domain of RNA Polymerase II. Mol Cell 60: 231-241

121. Conicella AE, Zerze GH, Mittal J, Fawzi NL (2016) ALS Mutations Disrupt Phase Separation Mediated by alpha-Helical Structure in the TDP-43 Low-Complexity C-Terminal Domain. Structure 24: 15371549

122. Mielke SP, Krishnan VV (2009) Characterization of protein secondary structure from NMR chemical shifts. Prog Nucl Magn Reson Spectrosc 54: 141-165

123. Brady JP, Farber PJ, Sekhar A, Lin YH, Huang R, Bah A, Nott TJ, Chan HS, Baldwin AJ, Forman-Kay JD, Kay LE (2017) Structural and hydrodynamic properties of an intrinsically disordered region of a germ cell-specific protein on phase separation. Proc Natl Acad Sci U S A 114: E8194-E8203

124. Clore GM, Iwahara J (2009) Theory, practice, and applications of paramagnetic relaxation enhancement for the characterization of transient low-population states of biological macromolecules and their complexes. Chem Rev 109: 4108-4139

125. Ramanujam V, Alderson TR, Pritisanac I, Ying J, Bax A (2020) Protein structural changes characterized by high-pressure, pulsed field gradient diffusion NMR spectroscopy. J Magn Reson 312: 106701

126. Dannatt HR, Felletti M, Jehle S, Wang Y, Emsley L, Dixon NE, Lesage A, Pintacuda G (2016) Weak and Transient Protein Interactions Determined by Solid-State NMR. Angew Chem Int Ed Engl 55: 66386641

127. Sigworth FJ (2016) Principles of cryo-EM single-particle image processing. Microscopy (Oxf) 65: 57-67

128. Franzmann TM, Jahnel M, Pozniakovsky A, Mahamid J, Holehouse AS, Nuske E, Richter D, Baumeister W, Grill SW, Pappu RV, Hyman AA, Alberti S (2018) Phase separation of a yeast prion protein promotes cellular fitness. Science 359: eaao5654

129. Schaffer M, Mahamid J, Engel BD, Laugks T, Baumeister W, Plitzko JM (2017) Optimized cryo-focused ion beam sample preparation aimed at in situ structural studies of membrane proteins. J Struct Biol 197: 73-82

130. Zaccai NR, Serdyuk IN, Zaccai G (2017) Methods in molecular biophysics : structure, dynamics, function for biology and medicine, Cambridge University Press, Cambridge

131. Sparks S, Temel DB, Rout MP, Cowburn D (2018) Deciphering the "Fuzzy" Interaction of FG Nucleoporins and Transport Factors Using Small-Angle Neutron Scattering. Structure 26: 477-484 e474

132. Mitrea DM, Chandra B, Ferrolino MC, Gibbs EB, Tolbert M, White MR, Kriwacki RW (2018) Methods for Physical Characterization of Phase-Separated Bodies and Membrane-less Organelles. J Mol Biol 430: 4773-4805

133. Murphy DB, Davidson M (2013) Fundamentals of light microscopy and electronic imaging, Wiley-Blackwell, Hoboken, N.J

134. Ambadipudi S, Biernat J, Riedel D, Mandelkow E, Zweckstetter M (2017) Liquid-liquid phase separation of the microtubule-binding repeats of the Alzheimer-related protein Tau. Nat Commun 8: 275

135. Strom AR, Emelyanov AV, Mir M, Fyodorov DV, Darzacq X, Karpen GH (2017) Phase separation drives heterochromatin domain formation. Nature 547: 241-245

136. Liu JL, Murphy C, Buszczak M, Clatterbuck S, Goodman R, Gall JG (2006) The Drosophila melanogaster Cajal body. J Cell Biol 172: 875884

137. Ishikawa-Ankerhold HC, Ankerhold R, Drummen GP (2012) Advanced fluorescence microscopy techniques--FRAP, FLIP, FLAP, FRET and FLIM. Molecules 17: 4047-4132

138. Chudakov DM, Matz MV, Lukyanov S, Lukyanov KA (2010) Fluorescent proteins and their applications in imaging living cells and tissues. Physiol Rev 90: 1103-1163 
139. Suzuki T, Matsuzaki T, Hagiwara H, Aoki T, Takata K (2007) Recent advances in fluorescent labeling techniques for fluorescence microscopy. Acta Histochem Cytochem 40: 131-137

140. Rashidian M, Dozier JK, Distefano MD (2013) Enzymatic labeling of proteins: techniques and approaches. Bioconjug Chem 24: 1277-1294

141. Tsien RY (1998) The green fluorescent protein. Annu Rev Biochem 67: 509-544

142. Jonkman J, Brown CM (2015) Any Way You Slice It-A Comparison of Confocal Microscopy Techniques. J Biomol Tech 26: 54-65

143. Schuler B (2013) Single-molecule FRET of protein structure and dynamics - a primer. J Nanobiotechnology 11 Suppl 1: S2

144. Elson EL (2011) Fluorescence correlation spectroscopy: past, present, future. Biophys J 101: 2855-2870

145. Ries J, Schwille P (2012) Fluorescence correlation spectroscopy. Bioessays 34: 361-368

146. Maharana S, Wang J, Papadopoulos DK, Richter D, Pozniakovsky A, Poser I, Bickle M, Rizk S, Guillen-Boixet J, Franzmann TM, Jahnel M, Marrone L, Chang YT, Sterneckert J, Tomancak P, Hyman AA, Alberti S (2018) RNA buffers the phase separation behavior of prion-like RNA binding proteins. Science 360: 918-921

147. Molenaar C, Weeks KL (2018) Nucleocytoplasmic shuttling: The ins and outs of quantitative imaging. Clin Exp Pharmacol Physiol 45: 1087-1094

148. Orlova EV, Saibil HR (2011) Structural analysis of macromolecular assemblies by electron microscopy. Chem Rev 111: 7710-7748

149. Williams DB, Carter CB (2009) Transmission electron microscopy : a textbook for materials science, Springer, New York

150. Scheer U, Weisenberger D (1994) The nucleolus. Curr Opin Cell Biol 6: 354-359
151. Sirri V, Hernandez-Verdun D, Roussel P (2002) Cyclin-dependent kinases govern formation and maintenance of the nucleolus. J Cell Biol 156: 969-981

152. Spector DL, Lamond AI (2011) Nuclear speckles. Cold Spring Harb Perspect Biol 3:

153. Gall JG, Bellini M, Wu Z, Murphy C (1999) Assembly of the nuclear transcription and processing machinery: Cajal bodies (coiled bodies) and transcriptosomes. Mol Biol Cell 10: 4385-4402

154. Bounedjah O, Desforges B, Wu TD, Pioche-Durieu C, Marco S, Hamon L, Curmi PA, Guerquin-Kern JL, Pietrement O, Pastre D (2014) Free mRNA in excess upon polysome dissociation is a scaffold for protein multimerization to form stress granules. Nucleic Acids Res 42: 8678-8691

155. Souquere S, Mollet S, Kress M, Dautry F, Pierron G, Weil D (2009) Unravelling the ultrastructure of stress granules and associated P-bodies in human cells. J Cell Sci 122: 3619-3626.

156. Souquere S, Weil D, Pierron G (2015) Comparative ultrastructure of CRM1-Nucleolar bodies (CNoBs), Intranucleolar bodies (INBs) and hybrid PML/p62 bodies uncovers new facets of nuclear body dynamic and diversity. Nucleus 6: 326-338

157. van de Corput MP, Grosveld FG (2001) Fluorescence in situ hybridization analysis of transcript dynamics in cells. Methods 25: 111-118

158. Dirks RW, Hattinger CM, Molenaar C, Snaar SP (1999) Synthesis, processing, and transport of RNA within the three-dimensional context of the cell nucleus. Crit Rev Eukaryot Gene Expr 9: 191-201

159. Kwon S (2013) Single-molecule fluorescence in situ hybridization: quantitative imaging of single RNA molecules. BMB Rep 46: 65-72

160. Sydor AM, Czymmek KJ, Puchner EM, Mennella V (2015) Super-Resolution Microscopy: From Single Molecules to Supramolecular Assemblies. Trends Cell Biol 25: 730-748

\title{
Membraneless organelles and liquid-liquid phase separation - methods for their characterisation
}

\section{Aneta Tarczewska*®, Krzysztof Wycisk*, Nikola Sozańska, Andrzej Ożyhar}

Department of Biochemistry, Molecular Biology and Biotechnology, Faculty of Chemistry, Wrocław University of Science and Technology, Wrocław

*Authors contributed equally to this work

${ }^{\circledR}$ Correspondence: aneta.tarczewska@pwr.edu.pl

Key words: membraneless organelles, MLOs, liquid-liquid phase separation, LLPS, phase transition, IDR

\begin{abstract}
Membraneless organelles (MLOs) are a large group of intracellular compartments formed during various stages of a cell life. They are important subcellular structures which enable a cell performance of vital physiological processes including stress response. MLOs can be found in cytoplasm and organelles that are sealed by lipidic membrane, mainly in nucleus. They are formed by the thermodynamically driven liquid-liquid phase separation (LLPS). MLOs contain proteins possessing intrinsically disordered regions (IDRs) which together with RNA spontaneously phase separate from the surrounding milieu. This paper presents information on the biophysical basses of the formation and functionality of MLOs. It also discusses a range of experimental techniques that can be applied in biochemical and biological studies of these sub-cellular structures.
\end{abstract}

